\title{
"Investor compensation fund: an optimal size for countries with developed stock markets and Ukraine"
}

\begin{tabular}{|c|c|}
\hline & Inna Shkolnyk iD https://orcid.org/0000-0002-5359-0521 \\
\hline & R http://www.researcherid.com/rid//-7368-2018 \\
\hline AUTHORS & Eugenia Bondarenko iD https://orcid.org/0000-0003-0525-6948 \\
\hline & R https://publons.com/researcher/3167105 \\
\hline & Myroslav Ostapenko \\
\hline ARTICLE INFO & $\begin{array}{l}\text { Inna Shkolnyk, Eugenia Bondarenko and Myroslav Ostapenko (2017). Investor } \\
\text { compensation fund: an optimal size for countries with developed stock markets } \\
\text { and Ukraine. Investment Management and Financial Innovations, 14(3), 404-425. } \\
\text { doi:10.21511/imfi.14(3-2).2017.10 }\end{array}$ \\
\hline DOI & http://dx.doi.org/10.21511/imfi.14(3-2).2017.10 \\
\hline RELEASED ON & Monday, 04 December 2017 \\
\hline RECEIVED ON & Monday, 23 October 2017 \\
\hline ACCEPTED ON & Friday, 17 November 2017 \\
\hline & $((c))$ EY-NC \\
\hline LICENSE & $\begin{array}{l}\text { This work is licensed under a Creative Commons Attribution-NonCommercial } 4.0 \\
\text { International License }\end{array}$ \\
\hline JOURNAL & "Investment Management and Financial Innovations" \\
\hline ISSN PRINT & $1810-4967$ \\
\hline SSN ONLINE & $1812-9358$ \\
\hline PUBLISHER & LLC "Consulting Publishing Company "Business Perspectives" \\
\hline UNDER & LLC "Consulting Publishing Company "Business Perspectives" \\
\hline
\end{tabular}

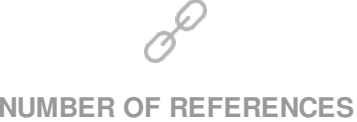

22

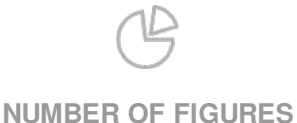

3
ニニ:

NUMBER OF TABLES

5

(C) The author(s) 2023. This publication is an open access article. 


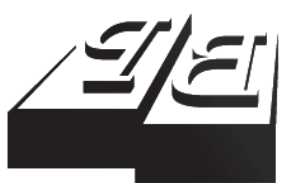

BUSINESS PERSPECTIVES

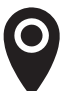

LLC "CPC "Business Perspectives" Hryhorii Skovoroda lane, 10, Sumy, 40022, Ukraine

www.businessperspectives.org

Received on: $23^{\text {rd }}$ of October, 2017 Accepted on: $17^{\text {th }}$ of November, 2017

(C) Inna Shkolnyk, Eugenia Bondarenko, Myroslav Ostapenko, 2017

Inna Shkolnyk, Dr., Professor, Head of Department of Finance, Banking and Insurance, Sumy State University, Ukraine.

Eugenia Bondarenko, Assistant, Department of Finance, Banking and Insurance, Sumy State University, Ukraine.

Myroslav Ostapenko, Ph.D. Student, Department of Finance, Banking and Insurance, Sumy State University, Ukraine.
Inna Shkolnyk (Ukraine), Eugenia Bondarenko (Ukraine),

Myroslav Ostapenko (Ukraine)

\section{INVESTOR COMPENSATION FUND: AN OPTIMAL SIZE FOR COUNTRIES WITH DEVELOPED STOCK MARKETS AND UKRAINE}

\begin{abstract}
A compensation fund is an effective mechanism for ensuring the protection of individual investors' investments on the stock market, which confirms the experience of different countries both with the developed stock market and with the emerging markets (USA, UK, France, Czech Republic, Bulgaria, Ireland, Malta).

The formation of a steady interest of individual investors in stock market instruments is stimulated by the implementation of a mechanism for guaranteeing such investments. The stock market of Ukraine faces the problem of attracting additional financing, while individual investors have fairly large amounts of monetary resources that are not involved in the transactions with financial instruments due to the high level of distrust caused by the crisis phenomena on both the global and the national financial markets. The creation of the Ukrainian compensation fund for investment protection involves the development and implementation of a nationwide system for protecting the property interests of investors on the stock market, which requires compensatory payments to the clients of all professional market participants as a result of certain risks.

The main condition for effective functioning of the compensation fund of the stock market is determined by its size, which must meet the following conditions of optimality: to ensure the minimum level of the fund's risks, to take into account the amounts of contributions for the current period, the amount of maintenance costs and to fulfil the requirements for the financial stability of the fund. A modified Markowitz portfolio model was used to build the model.
\end{abstract}

The building of the target function and constraints was carried out by using the Statistica software toolkit. The target function and constraints were presented as polynomials of the third degree and calculated with the help of the multiple nonlinear regression. As a result of calculations, an optimization model was developed for determining the size of the compensation fund taking into account these conditions.

The model's testing was carried out by using the examples of the Deposit Guarantee Fund (DGF) and compensation funds of the United States, Great Britain, France, Czech Republic, Bulgaria, Ireland and Malta. As a result of calculations we determined the size of the compensation fund, which guarantees a minimum level of the fund's risk taking into account the amount of contributions for the current period, the amount of maintenance costs and requirements to the financial stability of the fund.

\section{Keywords}

JEL Classification stock market, investment protection, individual investors, compensation fund, optimization

G28, G32

\section{(ㄷ)(1) $(8$}

This is an Open Access article, distributed under the terms of the Creative Commons Attribution-NonCommercial 4.0 International license, which permits re-use, distribution, and reproduction, provided the materials aren't used for commercial purposes and the original work is properly cited.

\section{INTRODUCTION}

According to Chernadchuk, Sukhonos, and Shkolnyk (2017), modern world financial architecture mainly involves the formation of financial systems according to two models, namely bank-based and marketbased, which is a prerequisite for the historically driven development of financial regulation. 
Ukraine has a number of criteria according to which the country's financial system can be defined as a bank-centered one, but taking into account the National Bank of Ukraine's policy on the banking system purgation, a significant part of depositors lost their savings, which led to a decrease in trust and outflow of depositors from banks. It should be noted that this problem is characteristic not only for Ukraine, but also for a number of European countries, as well as for the Asian region countries. At first, the financial crisis of 2008, and then further crisis phenomena did not contribute to restoring confidence in the Ukraine's banking system, despite guarantee fund for individuals. The problems of deposit insurance and its impact on the financial stability of the country and the region as a whole are becoming more widespread in the researches from different countries and different regions. So, Malaysian scholars Suhal Kusairi, Nur Azura Sanusi, Abdul Ghafar Ismail (2015) examine the effects of deposit insurance on the banking system in the Asian region. On the other hand, research findings in other countries, in particular in the Slovak Republic, indicate there is a significant amount of investment and financial products that can be used to capitalize savings, while investors prefer a more traditional form of capitalization - savings accounts in banks (Meheš, Stašková, Feranecová, \& Ragániová, 2016).

In Ukraine, unlike the Slovak Republic, proposal for investment and financial products is extremely limited, which leads to an increase in risks of depositors who are able to save their funds only in deposits. In such a situation, stock market could be a possible alternative to the funds distribution for both the population and enterprises, provided that there would be a certain compensatory mechanism that would protect depositors' interests through the protection of professional stock market participants' interests, similarly to both in the banking system of Ukraine and in most banking systems of other countries. In such a case, one can agree with Muhammad Mahboob Ali, Aviral Kumar Tiwari and Naveed Raza (2017) that the functioning of the stock market and the banking system are closely interconnected, especially in countries where the stock market is only in the forming stage and does not have a significant impact on the state of the economy, besides, it is characterized by negative phenomena such as opacity, corruption, high speculative operations and fraud.

In this context, one of the effective mechanisms for ensuring the protection of investments of individual investors on the stock market is the creation of a compensation fund. The existence of such a fund is an additional incentive for making a decision about investment on the stock market. The internal longterm investors form the basis for the market's stability. That is why their presence is extremely important. Compensation schemes have an extensive experience of effective operations in many countries with developed stock markets (USA, Canada, France, UK, Hong Kong, Australia, Singapore, Japan, etc.) and on emerging markets (Argentina, Brazil, Korea, South Africa, Malaysia, Mexico, Bulgaria, etc.).

In some countries, a compensation scheme involves a wider range of risks, for example, in Australia, the program protects against non-fulfillment of contracts, in the UK and the US - from certain fraudulent actions. However, such programs do not protect investments from the usual market risks, from the falling of the market value of securities. Mike Dempsey, Xiaofeng Shi Huu Nhan Duong, Petko S. Kalev (2015), Alisia J. Davis (2007), Adam C. Pritchard (1999), Thomas W. Joo (1999) examine the problems of supervision over the activity of financial intermediaries - brokers and dealers, as well as the problems of fraud on the stock market and the possible ways to deal with them. Compensation schemes provide the insurance of investments of individual investors. Inaccessibility of investments (monetary resources and securities) implies that they cannot be returned to individual investors as a result of insolvency (bankruptcy) of professional stock market participants.

The stock market of Ukraine encounters the problem of attracting additional financing: both from external and internal sources. The lack of free financial resources, which can be used for stock market operations, is related to the protracted political and economic instability. A significant source of additional financing for the stock market may become temporarily available free funds of domestic and foreign individual investors (Slav'yuk, Shkvarchuk, Kondrat, 2017). At the same time, increasingly relevant are 
the processes of convergence on the financial market, which create even more opportunities for financial intermediaries and individual investors, but which are accompanied by increased risks (Kozmenko, Pakhnenko, 2012).

In order to create a steady interest of individual investors in stock market instruments, it is necessary to develop and implement the mechanisms for guaranteeing such investments that will stimulate the development of the stock market. According to the foreign experience, a compensation fund is one of the most effective measures for attracting individual investors to the stock market, along with tax incentives, the introduction of an institute of investment consultants and the implementation of programs to increase the level of financial literacy of the population. The creation of the Ukrainian compensation fund for investment protection involves the development and implementation of a nationwide system for protecting the property interests of investors on the stock market, which requires compensatory payments to the clients of all professional market participants as a result of certain risks (1). Ukraine has some experience of compensation funds in the form of the Deposit Guarantee Fund (DGF), which essentially serves as a bank deposit insurance (Shkolnyk, Bukhtiarova, 2015), but only the first steps are taken towards the creation of a compensation fund.

The basic document governing the creation and functioning of compensation schemes for the EU countries is the 1997 Directive of the European Union (Directive 97/9/EC). On the basis of this document, national normative documents and regulatory mechanisms for each EU country are developed. Due to the fact that Ukraine has committed itself to bring its national legislation in line with the legislation of the European Union, it is necessary to implement the Directive 97/9/EC of the European Parliament of March 3, 1997 "On investor-compensation schemes".

We can conclude that the Ukrainian stock market requires the creation of a similar compensation fund, which will increase the interest of individual investors in market instruments and help accelerate its development, because it has already been proved that the level of protection of investors' interests on the market directly affects its development, including the liquidity of the market.

The size of the fund depends on the probability of emergence of foundations for the payment of compensations. In general, it should be at least $5-10 \%$ of the size of the maximum guarantees. The size of the maximum guarantees is the total amount of monetary resources and securities of individual investors on the accounts of the fund's members (professional stock market participants). The resources of the fund must be formed to the extent that it can compensate all losses of unqualified individual investors that arise as a result of inability of the fund's member to return the money and securities belonging to the client.

A compensation fund is an integral part of the protection system of retail customers, which also includes a risk-based supervision. The participation of state authorities in the field of the stock market and self-regulated organizations in the system of such supervision will minimize the likelihood of payments from the fund, and, hence, the financing by the conscientious and more stable members of the fund of less stable members. Investor protection programs are effective only under the condition of adequate supervision and regulation of the activities of professional stock market participants. Without this, the costs of supporting the programs and paying compensations to clients of insolvent and unscrupulous companies are excessively high and may exceed the potential of the conscientious market participants.

The main source of replenishment of such fund is the contributions of its members. For Ukraine, it would be advisable to introduce the following types of contributions: admission, quarterly (to be adjusted according to the risk profile of the fund member) and additional contributions in the event of the fund's deficit. The calculation of the size of contributions should be made by using economic and mathematical methods taking into account the specific features of activities of the fund's members 
on the stock market, the volume of the carried out transactions and the ability of the members to pay contributions.

It is also necessary to grant the fund the right to invest its temporarily available free funds and to obtain credit resources in case of the fund's deficit.

Since one of the most important indicators of the activity of any compensation fund is an indicator of its size, its management is faced with the task of ensuring its effective functioning, which implies the fund's ability to make compensatory payments at any time and in any amount. A precondition for effective functioning of any compensation fund is the calculation of its optimal size. An optimal size is the size, which ensures the minimal level of the fund's risk taking into account the contributions for the current period, the maintenance costs and the requirements of the fund's financial stability.

\section{OUTPUT DATA OF RESEARCH}

For the purpose of this study, we have used the information about compensation funds around the world, in particular: The Investor Compensation Fund (Bulgaria), Securities Investor Protection Corporation (United States of America), Investor Compensation Fund (Czech Republic), Financial Services Compensation Scheme (Great Britain). The Funds of the Guarantees for Dépôts et de Résolution (France), Investor Compensation Company Limited (Ireland) and Investor Compensation Scheme (Malta). Considering that in Ukraine, there is no such fund yet, in order to calculate and determine the optimal size of the fund, we used the information on the financial condition of professional participants of the domestic stock market and the data of the Deposit Guarantee Fund. The output data for the optimization model for each individual compensation fund vary, that is, the periods for which the information for calculations is derived are different and depend on the number of years of the fund's functioning and the availability of information about its operations. All data for the calculations were taken only from the official reports of such funds, which guarantees their reliability.

\section{METHODOLOGY}

The calculation of the optimal size of a particular compensation fund is carried out by taking into account certain constraints (conditional optimization). In our study, the basis for the optimization model is a classic Markowitz portfolio model, which is an approach based on the analysis of the expected average values and variations of random variables. The Markowitz model is aimed at creating an investment portfolio consisting of assets that meet certain criteria for the risk/return ratio. The expected return on the portfolio as a whole is defined as the average value of the distribution of return on the assets that form the portfolio. The expected portfolio risk is a standard deviation of the possible values of returns from their mathematical expectation. Therefore, the goal of the Markowitz model is to select the optimal investment portfolio from a set of possible portfolios.

It is assumed that in selecting a portfolio from two portfolios with the same expected return, an investor chooses a lower risk portfolio. Aiming to simultaneously maximize the expected profitability and to minimize uncertainties (risks) an investor has two goals that are contradictory and which should be balanced. The Markowitz approach makes it possible to take into account these two goals at the same time.

Since in our case we do not have to choose an investment portfolio, it is necessary to transform the Markowitz model in accordance with the research needs. The optimization model can have two tasks: direct and inverse. The direct task is to find the maximum value of any economic value, usually of income or profitability. The inverse task, on the contrary, is aimed at minimizing the risks of a particular economic phenomenon.

The optimization model in its general form has the following structure: the target function, the feasible region and the system of constraints that 
determine this area. At the same time, the target function consists of three elements: controllable variables, uncontrollable variables, forms of the function (the type of dependence between controllable and uncontrollable variables).

The building of the optimization econometric model requires the implementation of six stages. During the first stage, we will define optimization tasks for our study. Since the task of the optimization model can be defined both as the finding of the maximal and the minimal economic value, we will consider which of these tasks is relevant for determining the optimal amount of any compensation fund. When setting the maximal task, we obtain the maximum value of the compensation fund if certain conditions are met, but the maximum value of the compensation fund is not its optimal value from the point of view of ensuring the implementation of the fund's functions and maintaining an adequate financial burden on the fund's members. Therefore, it is necessary to set the minimal task, not the minimal size of the compensation fund, but the minimal risk of changes in the size of such fund. The changing size of the fund is calculated by us as a standard deviation (sample variance), which is calculated by the formula:

$$
S=\sqrt{\frac{1}{n} \sum_{i=1}^{n}\left(x_{i}-\bar{x}\right)^{2}} .
$$

Thus, an optimization model for determining the size of the funds hould be aimed at minimizing the risk of changes in the compensation fund subject to certain restrictions.

At the second stage, it is necessary to determine the variables of the optimization model. After analyzing the activities of compensation funds in more than 10 countries of the world, we came to the conclusion that the following factors influence the determination of the size of the fund: the size of the estimated expenditures of the fund, the contributions of the fund's participants (introductory, regular, special), the amount of compensation payments, as well as the ratio of the fund's size to the size of assets subject to the fund's insurance.

Accordingly, we have selected the variables that should be part of the model: $y$ - the risk of changes in the fund's size (standard deviation of the fund's size); $x$ - the size of the compensation fund; $c$ - contributions of the fund's members; $e$ - operating (estimated) expenses; $a$ - the size of assets insured by the compensation fund. In the model, we do not take into account the size of compensatory payments, because they are difficult to predict and it is impossible to determine their boundaries. This is due to the fact that in one period, there will be no compensatory payments at all, or they will be minimal, and in the other period, compensatory payments will be substantial. Both situations are normal for the compensation fund.

At the fourth stage, it is necessary to build a structural model in its general form. The objective function of the optimization model is the dependence of the risk of changes in the size of the compensation fund $(y)$ on the size of such compensation fund $(x)$ that can be described with the help of a multiple nonlinear regression. The following factor features were determined: $x, \cos x$ and $\sin x$, which are described by a polynomial function of the third degree, since the polynomials of different degrees optimally describe the economic phenomena and processes. Therefore, the target function of the optimization model looks like this:

$$
\begin{aligned}
& y=b_{0}+b_{1} \cdot x+b_{2} \cdot x^{2}+b_{3} \cdot x^{3}+b_{4} \cdot \cos x+ \\
& +b_{5} \cdot \cos x^{2}+b_{6} \cdot \cos x^{3}+b_{7} \cdot \sin x+ \\
& +b_{8} \cdot \sin x^{2}+b_{9} \cdot \sin x^{3}
\end{aligned}
$$

where $b_{0}$ is a constant term of the model; $b_{i}$ - the model parameters characterizing the influence of each factor on the resulting sign, $i \in(1.9)$.

After determining the target function, it is necessary to define a system of constraints that will help us determine the optimal size of a specific compensation fund. The first constraint relates to the size of contributions of the fund's members. To determine the left side of the first constraint, it is necessary to calculate the multiple nonlinear regression that describes the dependence of contributions $(c)$ on the size of the fund $(x), \cos x$ and $\sin x$. The amount of contributions (the left side) should be more than $80 \%$ of their mathematical expectation $(M(c))$ - the right side of inequality.

The second and the third constraints are related to the size of operating expenses of the compen- 
sation fund. The left side of both constraints is a function of dependence of the size of operating costs $(e)$ on the size of the fund $(x), \cos x$ and $\sin x$. The left side should be less than $120 \%$ of the maximum size of transaction costs $(\max (e))$ for the researched period (the right part of the second constraint) and more than $80 \%$ of the mathematical expectation of operating costs $(M(e))$ (the right part of the third constraint).

The fourth constraint of the system characterizes the requirement of financial stability of the compensation fund. The financial soundness of the compensation fund is calculated as the ratio between the size of the fund $(x)$ and the volume of the insured assets $a$ (formula 3 ). According to the international practice of the functioning of similar funds, the index of financial stability should be in the range from 5 to $10 \%$. For Ukraine, it is proposed to set a standard - not lower than $5 \%$.

$$
F S_{i}=\frac{F R_{i}}{G I P P_{i}} \cdot 100 \%,
$$

where $F S_{i}$ - financial stability of the compensation fund as of the beginning of the $i$-th month;

$F R_{i}$ - the sum of financial resources of the compensation fund at the beginning of the month and the fees of its members that must be received during the $i$-th month;

GIPP - the guaranteed amount of investments of physical persons on the stock market (monetary resources and securities on the accounts of members of the compensation fund belonging to individual investors) determined as of the beginning of the $i$-th month.

The fifth and the sixth constraints indicate that the size of the fund $(x)$ and the risk of changes in the size of the fund $(y)$ should be positive values.

Therefore, in general terms, we obtain the following optimization model:

$$
\begin{aligned}
& y=b_{0}+b_{1} \cdot x+b_{2} \cdot x^{2}+b_{3} \cdot x^{3}+b_{4} \cdot \cos x+ \\
& +b_{5} \cdot \cos x^{2}+b_{6} \cdot \cos x^{3}+b_{7} \cdot \sin x+ \\
& +b_{8} \cdot \sin x^{2}+b_{9} \cdot \sin x^{3} \rightarrow \min
\end{aligned}
$$

$$
\left\{\begin{array}{l}
c=d_{0}+d_{1} \cdot x+d_{2} \cdot x^{2}+d_{3} \cdot x^{3}+d_{4} \cdot \cos x+ \\
+d_{5} \cdot \cos x^{2}+d_{6} \cdot \cos x^{3}+d_{7} \cdot \sin x+ \\
+d_{8} \cdot \sin x^{2}+d_{9} \cdot \sin x^{3} \geq M(c) \cdot 0,8 \\
e=g_{0}+g_{1} \cdot x+g_{2} \cdot x^{2}+g_{3} \cdot x^{3}+g_{4} \cdot \cos x+ \\
+g_{5} \cdot \cos x^{2}+g_{6} \cdot \cos x^{3}+g_{7} \cdot \sin x+ \\
+g_{8} \cdot \sin x^{2}+g_{9} \cdot \sin x^{3} \leq \max (e) \cdot 1,2 \\
e=g_{0}+g_{1} \cdot x+g_{2} \cdot x^{2}+g_{3} \cdot x^{3}+g_{4} \cdot \cos x+ \\
+g_{5} \cdot \cos x^{2}+g_{6} \cdot \cos x^{3}+g_{7} \cdot \sin x+ \\
+g_{8} \cdot \sin x^{2}+g_{9} \cdot \sin x^{3} \geq M(e) \cdot 0,8 \\
\frac{x}{a} \geq 0.05 \\
x, y \geq 0
\end{array}\right.
$$

where $d_{0}$ and $g_{0}$ are constant terms in constraint functions; $d_{i}$ and $g_{i}$ - parameters of constraint functions characterizing the influence of each factor on the resulting sign, $i \in(1.9)$.

Problem formulation for the optimization task in this form will make it possible to calculate the optimal size of the compensation fund if the specified conditions are met.

Implementation of the fifth and the sixth stage is possible only by solving the optimization task on the example of the specific compensation funds.

In order to determine the reliability of the proposed model, it is necessary to test it by using an example of the existing compensation funds.

\section{FINDINGS}

It was decided to calculate the optimal amount of the Deposit Guarantee Fund due to the fact that this fund is a compensation fund and has more than 15 years of experience in Ukraine. In addition, we propose to create a fund for guaranteeing investments of individuals' on the stock market on the basis of the Deposit Guarantee Fund. Output data for calculations are given in Table 1.

To build an optimization model for the Deposit Guarantee Fund, we need to build three regression 
Table 1. Output data for calculating the optimal size of the Deposit Guarantee Fund for 2006-2016

\begin{tabular}{|c|c|c|c|c|c|}
\hline Year & $\begin{array}{l}\text { The amount } \\
\text { of the Deposit } \\
\text { Guarantee Fund, } \\
\text { mln. UAH } \\
(x)\end{array}$ & $\begin{array}{l}\text { The total amount of } \\
\text { contributions of the fund } \\
\text { members (initial and } \\
\text { regular), mln. UAH } \\
(c)\end{array}$ & $\begin{array}{l}\text { The sum of } \\
\text { operational } \\
\text { expenses of the } \\
\text { fund, mln. UAH } \\
(e)\end{array}$ & $\begin{array}{l}\text { Total amount of assets } \\
\text { subject to insurance } \\
\text { (deposits of physical } \\
\text { persons), bln. UAH } \\
\qquad(a)\end{array}$ & $\begin{array}{c}\text { Standard } \\
\text { deviation of } \\
\text { the fund's } \\
\text { size } \\
(y)\end{array}$ \\
\hline 2006 & 629.7 & 2635.7 & 10.13 & 67900 & 230.04 \\
\hline 2007 & 867 & 2874 & 11.75 & 100400 & 359.16 \\
\hline 2008 & 1335.5 & 3343.5 & 11.91 & 155200 & 1113.82 \\
\hline 2009 & 2987.3 & 4996.3 & 12.75 & 204900 & 1486.78 \\
\hline 2010 & 4302.7 & 6312.7 & 13.32 & 198000 & 673.94 \\
\hline 2011 & 3390.3 & 5401.3 & 24.33 & 254200 & 727.17 \\
\hline 2012 & 4827.3 & 6839.3 & 23.29 & 282600 & 1351.81 \\
\hline 2013 & 6092.1 & 8105.1 & 33.19 & 338500 & 1232.94 \\
\hline 2014 & 7292.9 & 9306.9 & 38 & 402600 & 5908.07 \\
\hline 2015 & 16872.6 & 18887.6 & 55.89 & 382100 & 4927.29 \\
\hline 2016 & 14084.4 & 16100.4 & 100.79 & 362300 & 1397.26 \\
\hline
\end{tabular}

equations (multiple nonlinear regression): for the target function and the first three constraints of the model. In order to perform calculations, it was decided to use the Statistica software instruments, which made it possible to assess the adequacy of the obtained functions and to determine the level of statistical significance of their parameters.

After the introduction of the variables, the program makes all the necessary calculations, the results of which for the target function of the Deposit Guarantee Fund are given in formula 5 and in Table 2 and Figure 1.

The determination coefficient $\left(R^{2}\right)$ is 0.95 , which is more than 0.75 and indicates a strong correlation between the resulting variable and predictors, as well as the importance of the constant term. On the basis of the data in Table 2, we see that for the nonlinear regression equation, the forward stepwise method includes the following variables: the volume of the fund $(x)$, the volume of the fund cubed $\left(x^{3}\right)$, and does not include the other six variables $\left(x^{2}, \cos x, \cos x^{2}, \cos x^{3}, \sin x^{2}, \sin x^{3}\right)$.

The target function of the optimization model for the Deposit Guarantee Fund is as follows:

$$
\begin{aligned}
& y=139.708+0.2065 \cdot x-0.0000000006 \cdot x^{3}+ \\
& +135.5852 \cdot \sin x \rightarrow \min .
\end{aligned}
$$

One of the conditions for the correct use of regression analysis is the conformity of the law of distribution of excesses to the normal law. According

Table 2. The results of regression for the standard deviation of the size of the Deposit Guarantee

\begin{tabular}{|c|c|c|c|c|c|c|}
\hline \multirow[t]{2}{*}{$N=9$} & \multicolumn{6}{|c|}{$\begin{array}{l}\text { Regression results for the dependent variable: } y \text { (target function of the Deposit Guarantee Fund) } \\
R=0.97591681 ; R^{2}=0.95241363 \text {. Corrected } R^{2}=0.92386180 \text {. } \\
F(3,5)=33.357 ; p<.00099 . \text { Standard error of assessment: } 141.94 \text {. }\end{array}$} \\
\hline & BETA & $\begin{array}{c}\text { Standard error } \\
\text { BETA }\end{array}$ & B & Standard error B & $t(5)$ & $p$-level \\
\hline Constant term & - & - & 139.7080 & 82.00172 & 1.70372 & 0.149160 \\
\hline$x$ & 1.768949 & 0.228299 & 0.2065 & 0.02666 & 7.74839 & 0.000572 \\
\hline$x^{3}$ & $-0,998255$ & 0.229553 & -0.0000 & 0.00000 & -4.34869 & 0.007368 \\
\hline $\sin x$ & 0.200228 & 0.098953 & 135.5852 & 67.00683 & 2.02345 & 0.098934 \\
\hline
\end{tabular}
Fund $(y)$ from its volume $(x)$ 


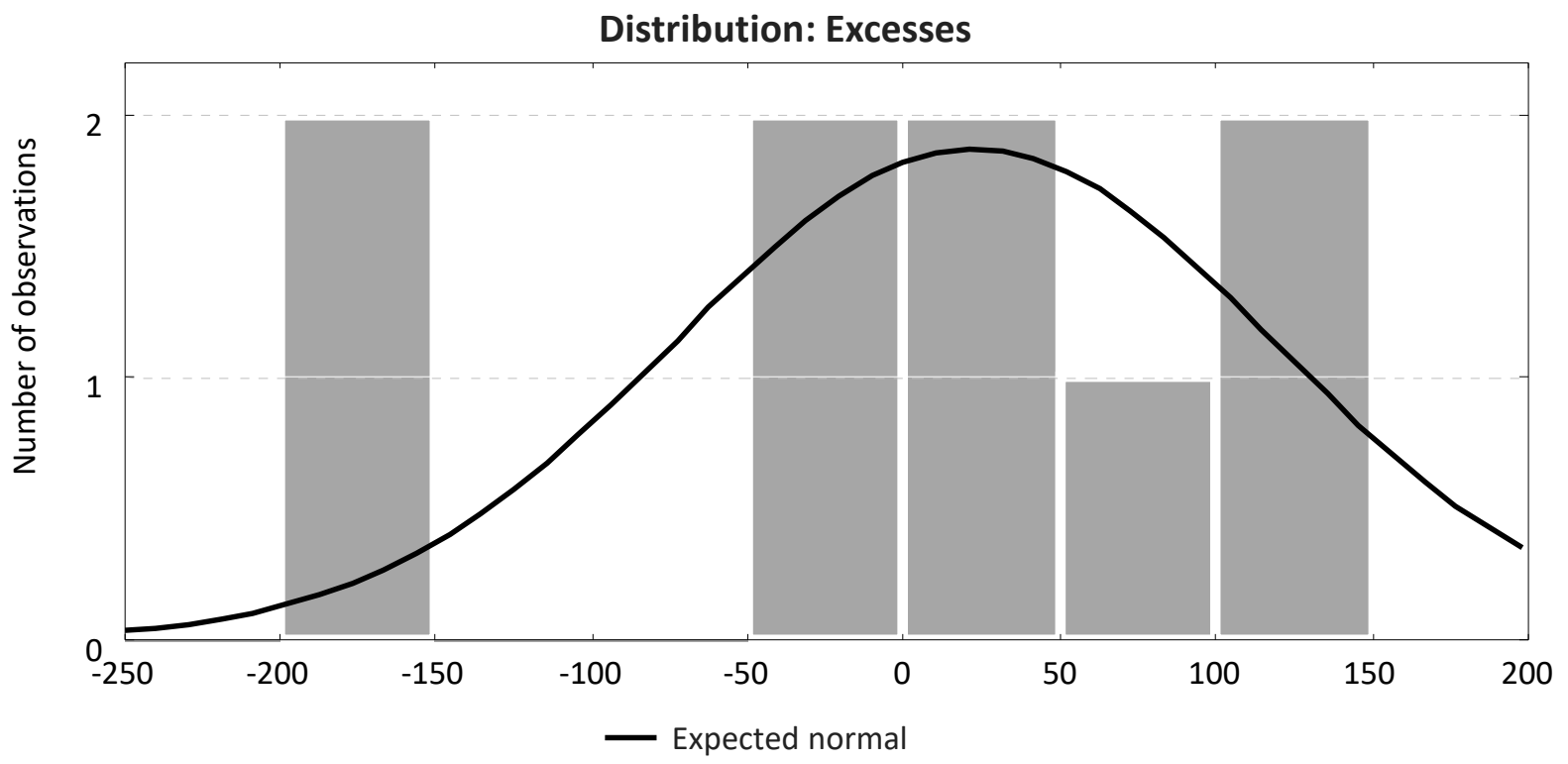

Figure 1. Distribution of excesses for the regression of standard deviation of the size of the Deposit Guarantee Fund $(y)$ from its volume $(x)$

to Figure 2, we can conclude that due to the small number of observations, the distribution of excesses does not conform to the normal law.

In general, based on the results of the regression analysis, we can make a conclusion about the high level of adequacy of the model for the dependence of deviation of the size of the Deposit Guarantee Fund $(y)$ on its volume $(x)$.

Similarly, calculations were made to determine the functions of constraints. The results of the calculations of the dependence of contributions from the members of the Deposit Guarantee Fund $(c)$ on the volume of the fund $(x)$ (the function of the first constraint) are shown in Table 3 and Figure 2.

According to the data in Table 3, the function of the first constraint of the model for the Deposit Guarantee Fund is as follows:

$$
\begin{aligned}
& c=109.0465+0.1315 \cdot x-0.0000000018 \cdot x^{3}+ \\
& +0.000034 \cdot x^{2} .
\end{aligned}
$$

The compliance of regression analysis (contributions from members of the Deposit Guarantee Fund $(c)$ from the volume of the fund $(x)$ of the law of distribution of excesses to the normal law is shown in Figure 2.

Table 3. The results of regression of contributions from the members of the Deposit Guarantee Fund

\begin{tabular}{|c|c|c|c|c|c|c|}
\hline \multirow[t]{2}{*}{$N=14$} & \multicolumn{6}{|c|}{$\begin{array}{l}\text { Regression results for the dependent variable: } c \text { (contributions of the Deposit Guarantee Fund) } \\
R=0.98657002 ; R^{2}=0.97332040 . \text { Corrected } R^{2}=0.96531652 . \\
F(3,10)=121.61 ; p<.00000 . \text { Standard error of assessment: } 217.81\end{array}$} \\
\hline & BETA & $\underset{\text { BETA }}{\text { Standard error }}$ & B & $\underset{B}{\text { Standard error }}$ & $t(10)$ & $p$-level \\
\hline Constant term & - & - & 109.0465 & 115.9378 & 0.94056 & 0.369095 \\
\hline$x$ & 0.58435 & 0.391347 & 0.1315485808 & 0.0881 & 1.49317 & 0.166255 \\
\hline$x^{3}$ & -2.20359 & 0.824826 & -0.0000000018 & 0.0000 & -2.67158 & 0.023429 \\
\hline$x^{2}$ & 2.49838 & 1.164030 & 0.0000339039 & 0.0000 & 2.14632 & 0.057420 \\
\hline
\end{tabular}
(c) from its volume $(x)$ 


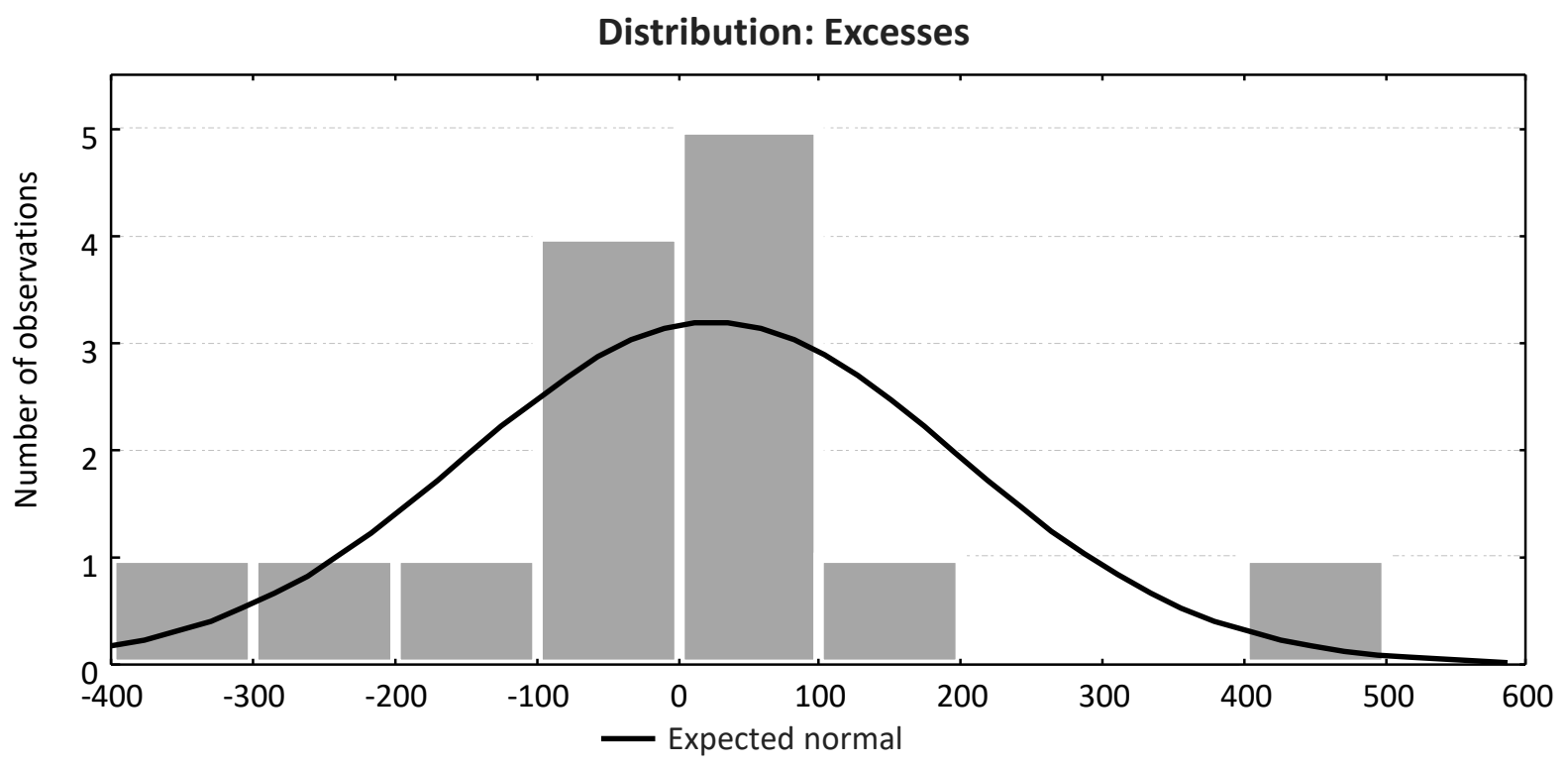

Figure 2. Distribution of excesses for the regression of contributions of members of the Deposit Guarantee Fund $(c)$ from its volume $(x)$

The results of calculations of the dependence of estimated costs of the Deposit Guarantee Fund $(e)$ on the volume of the fund $(x)$ are shown in Table 4 and Figure 3.

According to the data in Table 4, the function of the second and third constraints of the model for the Deposit Guarantee Fund is as follows:

$e=0.1308+0.0047 \cdot x-40.6892 \cdot \sin x+$

$+44.4162 \cdot(\sin x)^{3}$.
The compliance of regression analysis (estimated costs of the Deposit Guarantee Fund $c$ from the volume of the fund $(x)$ of the law of distribution of excesses to the normal law is shown in Figure 6.

As a result of calculations we have built the following optimization model for the Deposit Guarantee Fund:

$y=139.708+0.2065 \cdot x-0.0000000006 \cdot x^{3}+$ $+135.5852 \cdot \sin x \rightarrow \min$,

Table 4. The results of regression of the estimated costs of the Deposit Guarantee Fund $(e)$ from its volume $(x)$

\begin{tabular}{|c|c|c|c|c|c|c|}
\hline \multirow[t]{2}{*}{$N=11$} & \multicolumn{6}{|c|}{$\begin{array}{l}\text { Regression results for the dependent variable: } e \text { (estimated costs of the Deposit Guarantee Fund) } \\
R=.93352002 ; R_{2}=.87145963 . \text { Corrected } R_{2}=.81637090 . \\
F(3,7)=15.819 ; p<.00168 . \text { Standard error of assessment: } 11.705\end{array}$} \\
\hline & BETA & $\underset{\text { BETA }}{\text { Standard error }}$ & B & Standard error B & $t(7)$ & $p$-level \\
\hline Constant term & - & - & 0.1308 & 5.69651 & 0.02297 & 0.982317 \\
\hline$x$ & 0.91125 & 0.137212 & 0.0047 & 0.00071 & 6.64117 & 0.000293 \\
\hline $\sin x$ & -1.09302 & 0.431249 & -40.6892 & 16.05386 & -2.53454 & 0.038973 \\
\hline $\sin x^{3}$ & 0.97115 & 0.432057 & 44.4162 & 19.76036 & 2.24774 & 0.059396 \\
\hline
\end{tabular}


Distribution: Excesses

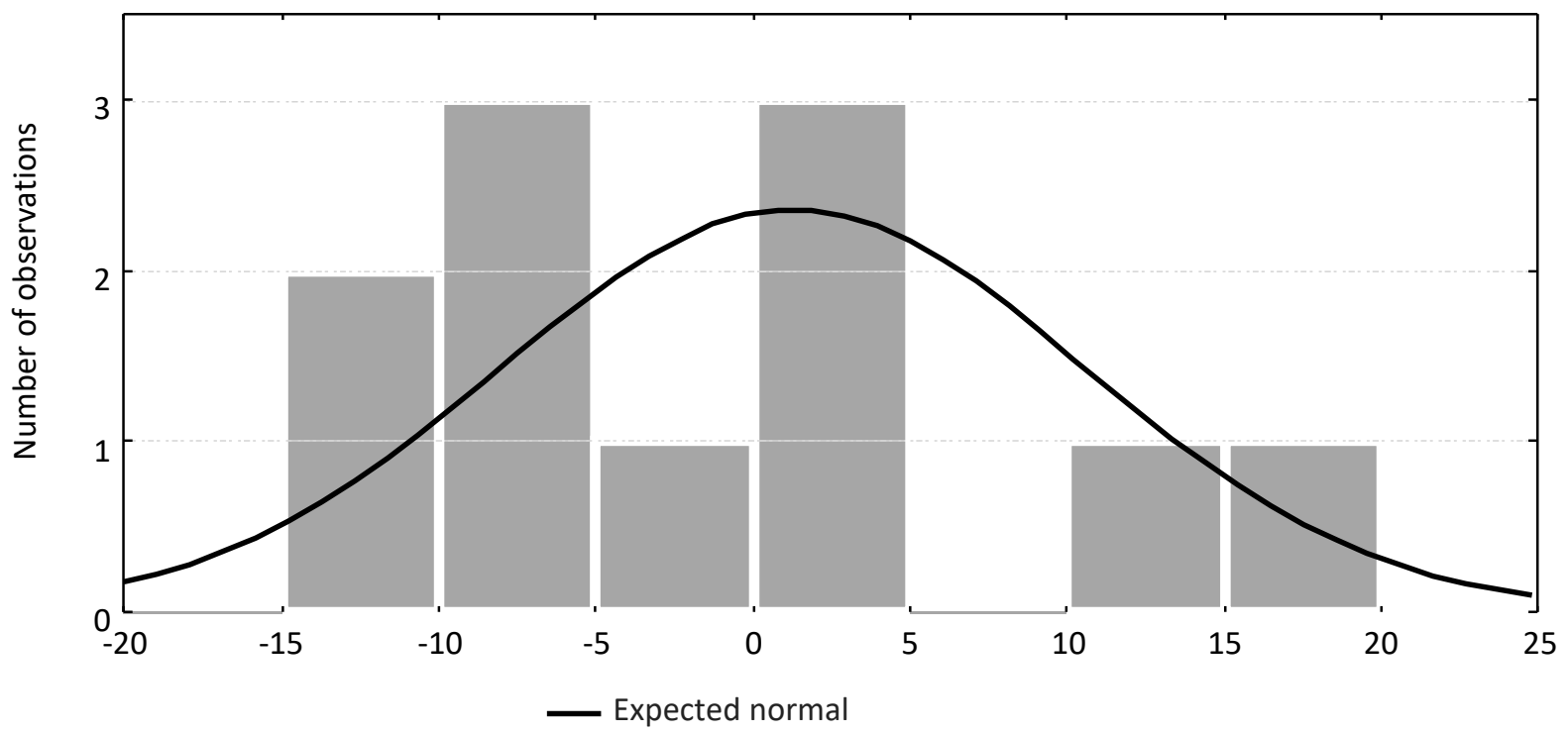

Figure 3. Distribution of excesses for the regression of estimated costs of the Deposit Guarantee Fund $(e)$ from the volume of the fund $(x)$

$$
\left\{\begin{array}{l}
c=109.0465+0.1315 \cdot x-0.0000000018 \cdot x^{3}+ \\
+0.000034 \cdot x^{2} \geq 1149.44 \\
e=0.1308+0.0047 \cdot x-40.6892 \cdot \sin x+ \\
+44.4162 \cdot(\sin x)^{3} \leq 120.95 \\
e=0.1308+0.0047 \cdot x-40.6892 \cdot \sin x+ \\
+44.4162 \cdot(\sin x)^{3} \geq 24.39 \\
\frac{x}{a} \geq 0.025 \\
x, y \geq 0 .
\end{array}\right.
$$

The fourth constraint characterizing the financial stability of the compensation funds should not be higher than $5 \%$ (the recommended international level), but $2 . \%$, since this norm is set for the Deposit Guarantee Fund by law.

Having obtained an optimization model for the Deposit Guarantee Fund, we can move to the fifth and the sixth stages of the model realization: elaboration of the development model and solution of the problem, as well as analysis of the optimal solution (checking it for adequacy and compliance with economic reality).

The model was developed with the help of the "Search for a solution" tool in the MS Excel program (Figure X.1). The data obtained as a result of implementation of the scientific and methodologi- cal approach to optimizing the size of the Deposit Guarantee Fund are given in Table 5.

On the basis of calculations given in Table 5 , it can be concluded that as of January 1, 2017, the optimal value of the Deposit Guarantee Fund amounted to 17999,76 million UAH. For the fund of this size, the contributions of its members amounted to 29994,54 million UAH and operating expenses - to $81 \mathrm{~m}$. 047, which is more than $2.5 \%$ proscribed by law approaching the recommended rate of $5 \%$. We also calculated the amount of contributions to the fund, administrative costs, the ratio of the fund's size to the volume of insured assets, as well as the value of the target function for the period 20062016. The value of the fund's size for calculations was used for the same period.

Similar calculations were made for investment compensation funds in other countries: The Investor Compensation Fund, Bulgaria (Appendix, Table 1), Securities Investor Protection Corporation, United States of America (Appendix A, Table 2), Investor Compensation Fund, Czech Republic (Appendix, Table 3), Financial Services Compensation Scheme, United Kingdom (Appendix, Table 4), The Fonds de garantie des dépôts et de résolution, France (Appendix, Table 5), Investor Compensation Company Limited, Ireland (Appendix, Table 6) and Investor Compensation Scheme, Malta (Appendix, Table 7). 
Table 5. The results of testing of the scientific and methodical approach to optimizing the volume of the Deposit Guarantee Fund, mln. UAH

\begin{tabular}{|c|c|c|c|c|c|}
\hline Year & $\begin{array}{l}\text { The volume of the } \\
\text { Deposit Guarantee } \\
\text { Fund } \\
(x)\end{array}$ & $\begin{array}{c}\text { Estimated amount of } \\
\text { contributions of the } \\
\text { fund's members } \\
(c)\end{array}$ & 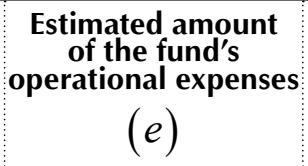 & $\begin{array}{l}\text { The ratio of the fund's } \\
\text { size to the volume of } \\
\text { insured assets } \\
(x / a)\end{array}$ & $\begin{array}{c}\begin{array}{c}\text { Target } \\
\text { function }\end{array} \\
(y)\end{array}$ \\
\hline 2006 & 629.7 & 204.88 & 5.21 & 0.009 & 402.75 \\
\hline 2007 & 867 & 247.44 & 7.41 & 0.0086 & 307.58 \\
\hline 2008 & 1335.5 & 341.02 & 17.91 & 0.0086 & 371.01 \\
\hline 2009 & 2987.3 & 757.31 & 1.90 & 0.015 & 787.67 \\
\hline 2010 & 4302.7 & 1160.92 & 20.24 & 0.022 & 850.45 \\
\hline 2011 & 3390.3 & 875.53 & 30.85 & 0.013 & 748.87 \\
\hline 2012 & 4827.3 & 1333.65 & 23.94 & 0.017 & 1200.66 \\
\hline 2013 & 6092.1 & 1765.04 & 43.7 & 0.018 & 1190.98 \\
\hline 2014 & 7292.9 & 2178.21 & 34.73 & 0.018 & 1283.73 \\
\hline 2015 & 16872.6 & 3361.01 & 68.76 & 0.044 & 847.59 \\
\hline 2016 & 14084.4 & 3676.67 & 81.17 & 0.039 & 1290.8 \\
\hline $\begin{array}{l}\text { Optimal value } \\
\text { considering all } \\
\text { constraints }\end{array}$ & 17999.76 & 2994.54 & 81 & 0.047 & 222.01 \\
\hline
\end{tabular}

\section{CONCLUSION}

The optimization model, which we have obtained, is somewhat narrow, since for our calculations, we used only open statistical information. But this methodological approach can be extended by the management of such fund, because they have access to all the information about its operations used to calculate its optimal size. The building of regression models for the dependence of the fund's size on a bigger number of variables will make it possible to create a model that will more adequately describe the economic reality and will yield more accurate results.

On the basis of calculations made for the Deposit Guarantee Fund, we can conclude that the proposed scientific and methodological approach to determining the optimal size of the fund makes it possible to determine the size of the compensation fund, which guarantees a minimum level of the fund's risk taking into account the amount of contributions for the current period, the amount of maintenance costs and the requirements for the fund's financial stability.

\section{REFERENCES}

1. Adam C. Pritchard. (1999). Markets as Monitors: A Proposalto Replace Class Actions with Exchangesas Securities Fraud Enforcers University of Michigan Law School. Retrieved from http:// repository.law.umich.edu/cgi/ viewcontent.cgi? article $=1512 \&$ co ntext $=$ articles

2. Ali, M. M., Tiwari, A. K., \& Raza, N. (2017). Impact of return on long-memory data setof volatility of Dhaka Stock Exchange market with the role of financial institutions: an empirical analysis. Banks and Bank Systems, 12(3), 48-60. https://doi. org/10.21511/bbs.12(3).2017.04

3. Annual Reports / Financial Services Compensation Scheme of United Kingdom. Retrieved from https:// www.fscs.org.uk/industry/publications/annual-reports/

4. Annual Reports and Financial Statements / Investor Compensation Scheme of Malta. Retrieved from http://www.compensationschemes.org.mt/Home/ ViewContent/35
5. Annual Report / Investor Compansation Fund of Bolgaria. Retrieved from http://sfund-bg. $\mathrm{com} /$ en/publications/annualreport-of-investor-compensationfund/

6. Annual Reports / Securities Investor Protection Corporation of United States of America. Retrieved from http://www.sipc. org/news-and-media/annualreports

7. Annual Reports / Investor Compansation Fund of Czech Republic. Retrieved 
from http://www.gfo.cz/page. php?show=vyrocni_zpravy

8. Annual Reports / Investor Compensation Company Limited of Ireland. Retrieved from https:// www.investorcompensation.ie/ publications/funding-publications.257.html

9. Chernadchuk, V., Sukhonos, V., Shkolnyk, I. (2017). The notion and content of financial system in the context of financial law of Ukraine. Problems and Perspectives in Management, 15(2-1), 34245. https://doi.org/10.21511/ ppm.15(2-1).2017.07

10. Dempsey, M., Xiaofeng, S., Duong, H. N., Kalev, P. S. (2015), Investor Protection and Market Liquidity Revisited, Corporate Governance. The International Journal of Businessin Society, 15(4), 517-529. https://dx.doi. org/10.1108/CG-04-2014-0046

11. Deposit Guarantee Fund. Retrieved from http://www.fg.gov. ua/about/report

12. Directive $97 / 9 / \mathrm{EC}$ of the European Parliament and of the Councilof 3 March 1997 on Investorcompensation schemes. Retrieved from http://eur-lex.europa.eu/ LexUriServ/LexUriServ.do?uri=CELEX:31997L0009:EN:HTML

13. Evaluation of the investment compensation scheme directive DG internal market and services: executive report and recommendations. Retrieved from https://ec.europa.eu/info/system/files/evaluation-investorcompensation-scheme-directive-022005_en.pdf

14. Evans, A. D. (2007) The investor compensation fund. The Journal of Corporation Law, 33(1), 223-296. Retrieved from http://lesliecaton. com/wordpress/wp-content/uploads/2012/01/A12-Evans.pdf

15. Financial Services Compensation Scheme. Retrieved from https:// www.fscs.org.uk/

16. French Documentation / Annual report / The Fonds de garantie des dépôts et de résolution of France. Retrieved from https://www.garantiedesdepots.fr/en/documentdatabase/fgdr-documents

17. Kozmenko, O., \& Pakhnenko, O. (2012). Securitization of bank assets and insuranceliabilities on the basis of the stock market potential. Insurance Markets and Companies: Analyses and Actuarial Computations, 3(2). Retrieved from https://businessperspectives. org/journals/insurance-marketsand-companies-analyses-andactuarial-computations/issue-200/ securitization-of-bank-assets-andinsurance-liabilities-on-the-basisof-the-stock-market-potential

18. Joo, T. W. Who watches the watchers? The securities investor protection act, investor confidence, and the subsidization of failure. Southern California Law Review, 72, 1071-1149. Retrieved from http://www-bcf.usc.edu/ usclrev/ pdf/072403.pdf

19. Kusairi, S., Sanusi, N. A., \& Ismail, A. G. (2015). Impact of deposit insurance on banking industry of ASEAN countries: in quest of stability. Banks and Bank Systems, 10(4), 41-50. Retrieved from https://businessperspectives.org/ journals/banks-and-bank-systems/ issue-187/impact-of-depositinsurance-on-banking-industryof-asean-countries-in-quest-ofstability

20. Meheš, M., Stašková, S., Feranecová, A., Ragániová, V. (2016). Selecting the savings account in the Slovak Republic. Problems and Perspectives in Management, 14(4), 8-16. https://doi.org/10.21511/ ppm.14(4).2016.01

21. Shkolnyk, I. O., Bukhtiarova, A. G. (2015). Investigation of causality of formation of deposit resources of individuals in Ukraine. The problems of economy, 2, 265-272.

22. Slav'yuk, R., Shkvarchuk, L., \& Kondrat, I. (2017). Financial market imbalance: reasons and peculiarities of occurrence in Ukraine. Investment Management and Financial Innovations, 14(1-1), 227-235. https://doi.org/10.21511/ imfi.14(1-1).2017.09 


\section{APPENDIX. RESULTS OF TESTING OF THE SCIENTIFIC AND METHODICAL APPROACH TO DETERMINING THE OPTIMAL SIZE OF THE COMPENSATION FUND}

\section{THE INVESTOR COMPENSATION FUND (BULGARIA)}

Table 1a. The results of regression of the standard deviation of the size of the Investor Compensation Fund (Bulgaria) $(y)$ from its volume $(x)$

\begin{tabular}{|c|c|c|c|c|c|c|}
\hline \multirow[t]{2}{*}{$N=8$} & \multicolumn{6}{|c|}{$\begin{array}{l}\text { Regression results for dependent variable: risk (data matrix 1) } \\
R=.96642941 ; R^{2}=.93398580 . \text { Corrected } R^{2}=.88447515 \\
F(3,4)=18.864 ; \quad p<.00799 . \text { Standard error of estimate: } .19486\end{array}$} \\
\hline & BETA & $\begin{array}{c}\text { Standard } \\
\text { error } \\
\text { BETA }\end{array}$ & B & $\begin{array}{c}\text { Standard } \\
\text { error B }\end{array}$ & $t(4)$ & $p$-level \\
\hline Free term & - & - & 0.968081 & 0.393536 & 2.45995 & 0.069695 \\
\hline$V_{2}^{2}$ & -3.34446 & 0.754734 & -0.035494 & 0.008010 & -4.43132 & 0.011410 \\
\hline fund & 2.36684 & 0.737060 & 0.384666 & 0.119789 & 3.21120 & 0.032552 \\
\hline $\sin e$ & -0.45574 & 0.147243 & -0.351038 & 0.113415 & -3.09517 & 0.036391 \\
\hline
\end{tabular}

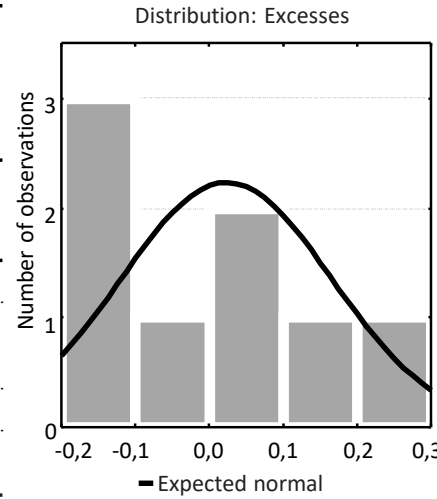

Table 1b. The results of regression of contributions from the members of the Investor Compensation Fund (Bulgaria) $(c)$ from its volume $(x)$

\begin{tabular}{|c|c|c|c|c|c|c|}
\hline \multirow[t]{2}{*}{$N=8$} & \multicolumn{6}{|c|}{$\begin{array}{l}\text { Regression results for dependent variable: contributions } \\
\text { (data matrix 1) } \\
R=.99845258 ; R^{2}=.99690756 \text {. Corrected } R^{2}=.98917645 \text {. } \\
F(5,2)=128.95 ; \quad p<.00771 \text {. Standard error of estimate: } .6753 \text {. }\end{array}$} \\
\hline & BETA & $\begin{array}{c}\text { Standard } \\
\text { error } \\
\text { BETA }\end{array}$ & B & $\begin{array}{c}\text { Standard } \\
\text { error B }\end{array}$ & $t(2)$ & $p$-level \\
\hline Free term & - & - & 1.163151 & 0.150964 & 7.7048 & 0.016431 \\
\hline$v_{2}^{2}$ & -3.13421 & 0.249267 & -0.037658 & 0.002995 & -12.5737 & 0.006266 \\
\hline $\cos x$ & 0.74691 & 0.047146 & 0.638575 & 0.040307 & 15.8426 & 0.003961 \\
\hline $\sin e$ & -0.64595 & 0.053633 & -0.563300 & 0.046770 & -12.0439 & 0.006823 \\
\hline fund & 1.84964 & 0.235196 & 0.340333 & 0.043276 & 7.8643 & 0.015787 \\
\hline$v_{3}^{2}$ & 0.25069 & 0.047904 & 0.444680 & 0.084973 & 5.2332 & 0.034629 \\
\hline
\end{tabular}

Table 1c. The results of regression of operating costs of the Investor Compensation Fund (Bulgaria) (e) from the volume of the fund $(x)$

\begin{tabular}{|c|c|c|c|c|c|c|}
\hline \multirow[t]{2}{*}{$N=8$} & \multicolumn{6}{|c|}{$\begin{array}{l}\text { Regression results for dependent variable: costs (data matrix 1) } \\
R=.98371013 ; R^{2}=.96768562 . \text { Corrected } R^{2}=.95475986 \\
F(2,5)=74.865 ; \quad p<.00019 . \text { Standard error of estimate: } .01722 \text {. }\end{array}$} \\
\hline & BETA & $\begin{array}{c}\text { Standard } \\
\text { error } \\
\text { BETA }\end{array}$ & B & $\begin{array}{c}\text { Standard } \\
\text { error B }\end{array}$ & $t(5)$ & $p$-level \\
\hline Free term & - & - & 0.076651 & 7357 & 4.41617 & 0.006917 \\
\hline fund & 0.904466 & 0.087002 & 0.020753 & 0.001996 & 10.39596 & 0.000142 \\
\hline $\sin e$ & -0.173049 & 0.087002 & -0.018818 & 0.009461 & -1.98903 & 0.103378 \\
\hline
\end{tabular}
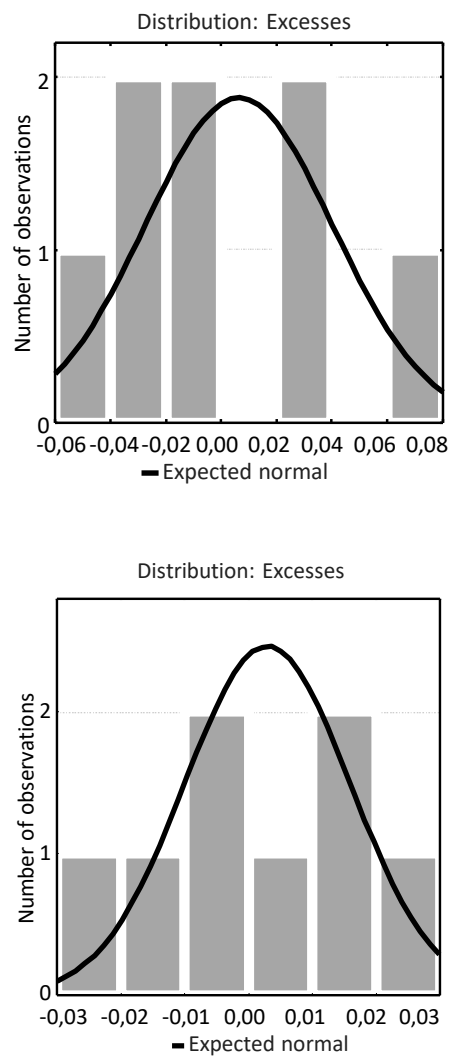
$y=0.968081-0.035494 \cdot x^{2}+0.384666 \cdot x-$

$-0.351038 \cdot \sin x \rightarrow \min$

$\left\{\begin{array}{l}c=1.163151-0.037658 \cdot x^{2}+0.638575 \cdot \cos x- \\ -0.5633 \cdot \sin x+0.340333 \cdot x+ \\ +0.444680 \cdot(\cos x)^{2} \geq 1.012 \\ e=0.076651+0.020753 \cdot x-0.018818 \cdot \sin x \leq 0.427 \\ e=0.076651+0.020753 \cdot x-0.018818 \cdot \sin x \geq 0.201 \\ \frac{x}{a} \geq 0.05 \\ x, y \geq 0\end{array}\right.$

\begin{tabular}{|c|c|c|c|}
\hline & $\begin{array}{c}\text { Target function } \\
(y)\end{array}$ & 0.7697 & \\
\hline & $\underset{(x)}{\text { Level of fund }}$ & 11.8542 & \\
\hline Fee limitations $(b)$ & 1.0120 & $>=$ & 1.01 \\
\hline \multirow[t]{2}{*}{$\begin{array}{l}\text { Operating cost } \\
\text { limitations }(c)\end{array}$} & 0.3350 & $<=$ & 0.43 \\
\hline & $c$ & $>=$ & 0.20 \\
\hline \multirow[t]{2}{*}{$\begin{array}{l}\text { Level of fund } \\
\text { limitation }\end{array}$} & 0,0826 & $>=$ & 0.05 \\
\hline & $x$ & $>$ & 0 \\
\hline
\end{tabular}

\section{SECURITIES INVESTOR PROTECTION CORPORATION (UNITED STATES OF AMERICA)}

Table 2a. The results of regression of the standard deviation of the size of the Securities Investor Protection Corporation (SIPC) $(y)$ from its volume $(x)$

\begin{tabular}{|c|c|c|c|c|c|c|}
\hline \multirow[t]{2}{*}{$N=12$} & \multicolumn{6}{|c|}{$\begin{array}{l}\text { Regression results for dependent variable: } \text { risk (USA target function) } \\
R=0.96807254 ; R^{2}=0.93716444 . \text { Corrected } R^{2}=0.88480148 . \\
F(5,6)=17.897 ; \quad p<.00151 . \text { Standard error of estimate: } .14029 .\end{array}$} \\
\hline & BETA & $\begin{array}{c}\text { Standard } \\
\text { error BETA }\end{array}$ & B & $\begin{array}{c}\text { Standard } \\
\text { error B }\end{array}$ & $t(6)$ & $p$-level \\
\hline Free term & - & - & 5272.7 & 9095.30 & 0.57972 & 0.583201 \\
\hline$x^{2}$ & 1.171863 & 0.265365 & 0.0 & 0.00 & 4.41604 & 0.004490 \\
\hline$(\sin x)^{3}$ & 1.263864 & 0.364210 & 89170.4 & 25696.40 & 3.47015 & 0.013301 \\
\hline $\sin x$ & -0.763928 & 0.335326 & -41060.8 & 18023.63 & -2.27816 & 0.062958 \\
\hline$x$ & -0.410631 & 0.278505 & -0.4 & 0.25 & -1.47441 & 0.190812 \\
\hline$(\sin x)^{2}$ & 0.162321 & 0.123968 & 21390.4 & 16336.31 & 1.30938 & 0.238310 \\
\hline
\end{tabular}

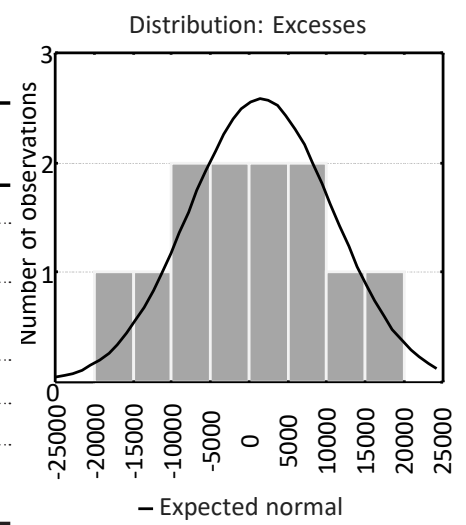

Table $\mathbf{2 b}$. The results of regression for contributions of the members of the Securities Investor Protection Corporation (SIPC) $(c)$ from its volume $(x)$

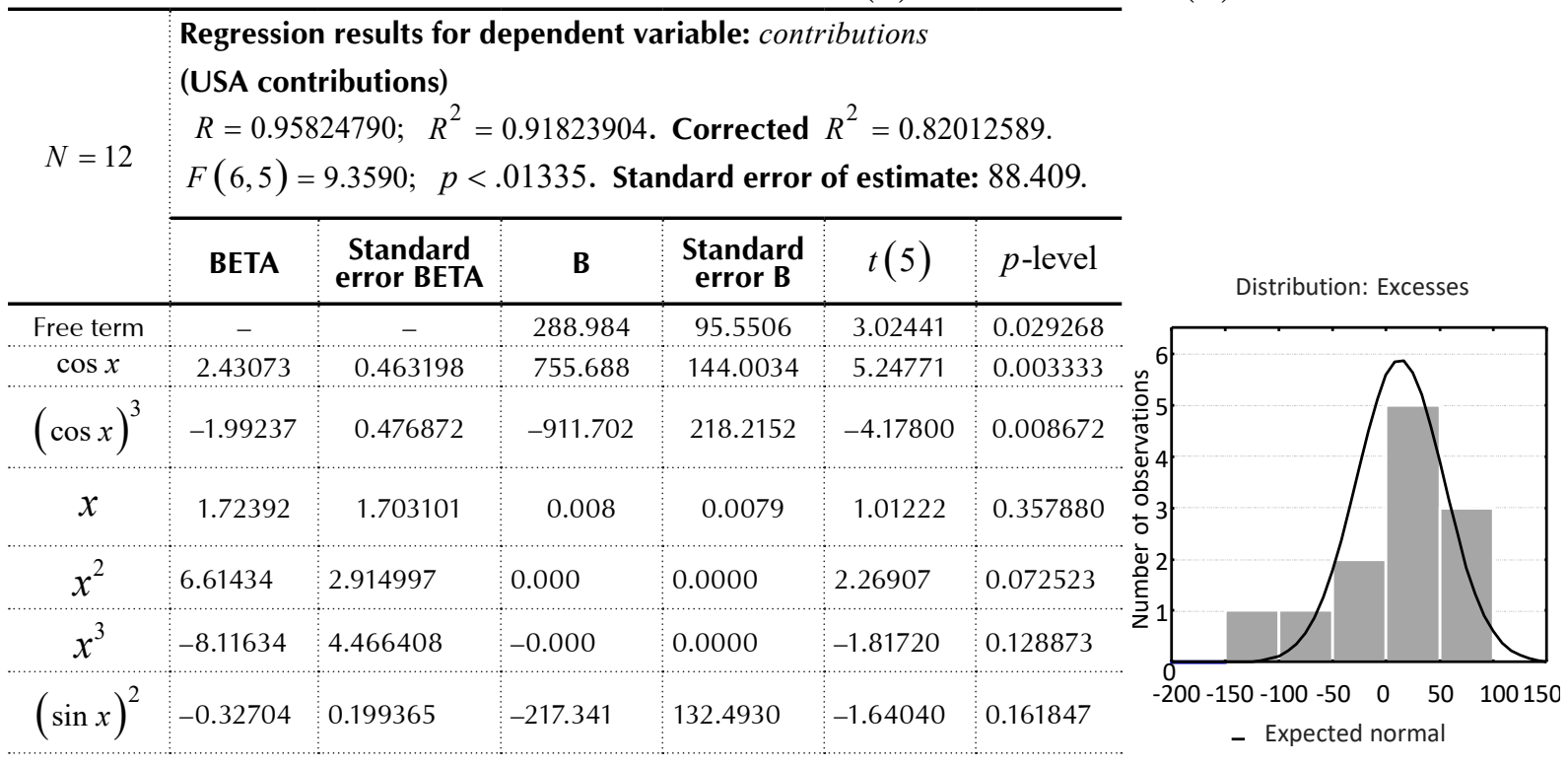


Table 2c. The results of regression for operating costs of the Securities Investor Protection Corporation (SIPC) $(e)$ from the fund's volume $(x)$

\begin{tabular}{|c|c|c|c|c|c|c|}
\hline \multirow[t]{2}{*}{$N=12$} & \multicolumn{6}{|c|}{$\begin{array}{l}\text { Regression results for dependent variable: } \text { costs } \\
\text { (USA operating expenses) } \\
R=0.98131437 ; \quad R^{2}=0.96297789 \text {. Corrected } R^{2}=0.89818919 . \\
F(7,4)=14.863 ; \quad p<.01014 \text {. Standard error of estimate: } 0.73062 \text {. }\end{array}$} \\
\hline & BETA & $\begin{array}{c}\text { Standard } \\
\text { error BETA }\end{array}$ & B & $\begin{array}{c}\text { Standard } \\
\text { error B }\end{array}$ & $t(4)$ & $p$-level \\
\hline Free term & - & - & 11.91764 & 0.506143 & 23.54600 & 0.000019 \\
\hline $\cos x$ & 1.9960 & 0.378669 & 6.81621 & 1.293137 & 5.27106 & 0.006208 \\
\hline$(\cos x)^{3}$ & -1.9551 & 0.371880 & -9.82737 & 1.869245 & -5.25740 & 0.006266 \\
\hline$x^{2}$ & 12.6494 & 2.204999 & 0.00000 & 0.000000 & 5.73669 & 0.004574 \\
\hline$x^{3}$ & -18.1455 & 3.377681 & -0.00000 & 0.000000 & -5.37217 & 0.005799 \\
\hline$x$ & 6.0110 & 1.281626 & 0.00030 & 0.000065 & 4.69013 & 0.009377 \\
\hline$(\sin x)^{3}$ & -0.3299 & 0.143218 & -1.28923 & 0.559756 & -2.30320 & 0.082648 \\
\hline$(\cos x)^{2}$ & -0.1540 & 0.152732 & -1.12385 & 1.114950 & -1.00799 & 0.370486 \\
\hline
\end{tabular}
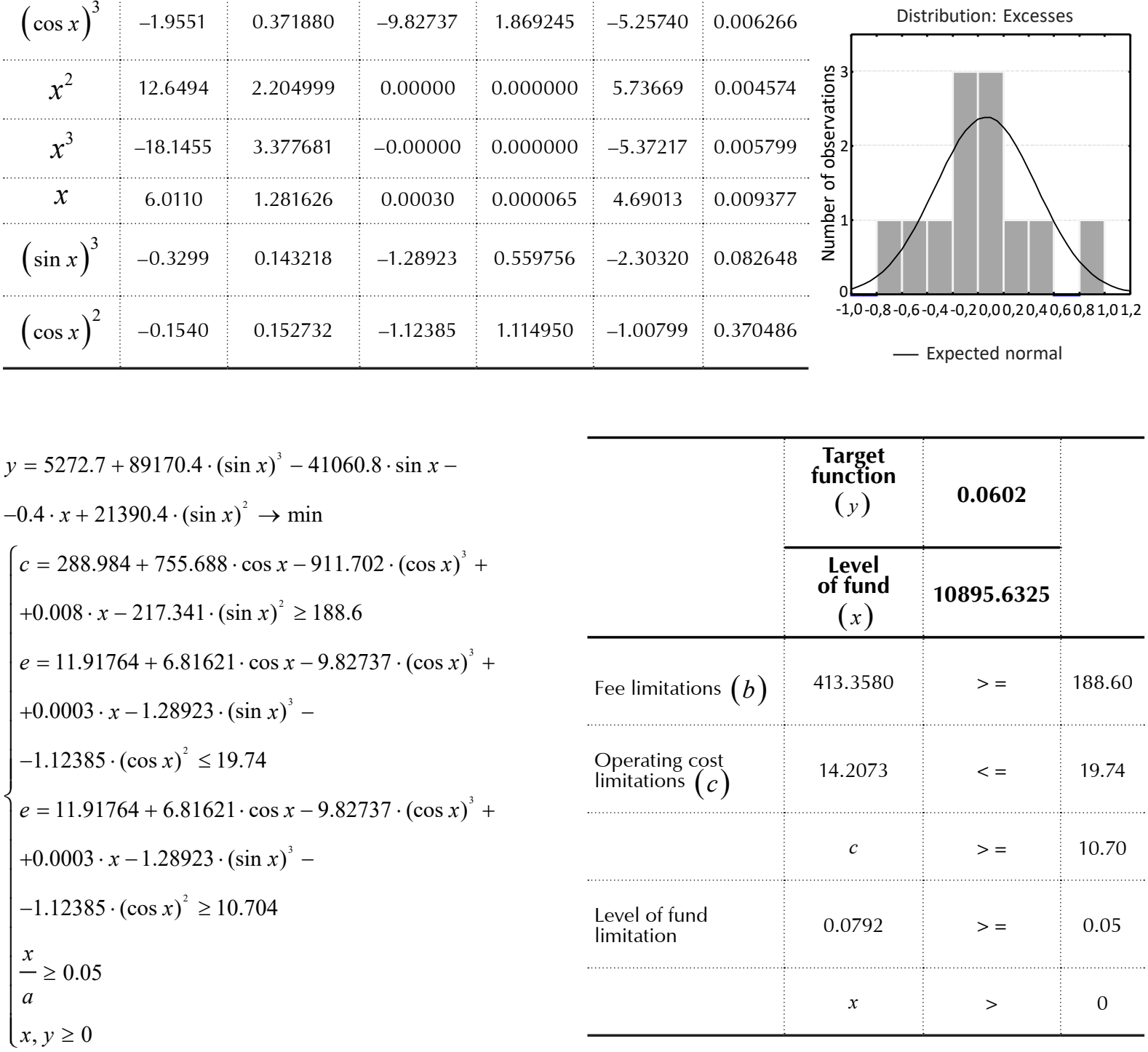

\begin{tabular}{|c|c|c|c|}
\hline & $\begin{array}{c}\text { Target } \\
\text { function } \\
(y)\end{array}$ & 0.0602 & \\
\hline & $\begin{array}{l}\text { Level } \\
\text { of fund } \\
(x)\end{array}$ & 10895.6325 & \\
\hline Fee limitations $(b)$ & 413.3580 & $>=$ & 188.60 \\
\hline \multirow[t]{2}{*}{$\begin{array}{l}\text { Operating cost } \\
\text { limitations }(c)\end{array}$} & 14.2073 & $<=$ & 19.74 \\
\hline & $c$ & $>=$ & 10.70 \\
\hline \multirow[t]{2}{*}{$\begin{array}{l}\text { Level of fund } \\
\text { limitation }\end{array}$} & 0.0792 & $>=$ & 0.05 \\
\hline & $x$ & $>$ & 0 \\
\hline
\end{tabular}




\section{INVESTOR COMPENSATION FUND (CHECH REPUBLIC)}

Table 3a. The results of regression for the standard deviation of the size of the Investor Compensation Fund (Czech Republic) $(y)$ from its volume $(x)$

\begin{tabular}{|c|c|c|c|c|c|c|}
\hline \multirow[t]{2}{*}{$N=9$} & \multicolumn{6}{|c|}{$\begin{array}{l}\text { Regression results for dependent variable: risk (Czech Republic target } \\
\text { function) } \\
R=0.92857026 ; \quad R^{2}=0.86224273 . \text { Corrected } R^{2}=0.81632364 \\
F(2,6)=18.777 ; \quad p<.00261 . \text { Standard error of estimate: } 12.921 .\end{array}$} \\
\hline & BETA & $\begin{array}{c}\text { Standard } \\
\text { error BETA }\end{array}$ & B & $\underset{\text { error B }}{\text { Standard }}$ & $t(6)$ & $p$-level \\
\hline Free term & - & - & 40.0923 & 6.708399 & 5.97643 & 0.000985 \\
\hline$x^{2}$ & 0.944546 & 0.154160 & 0.0002 & 0.000033 & 6.12704 & 0.000864 \\
\hline $\sin x$ & -0.192043 & 0.154160 & -10.1664 & 8.160959 & -1.24573 & 0.259300 \\
\hline
\end{tabular}

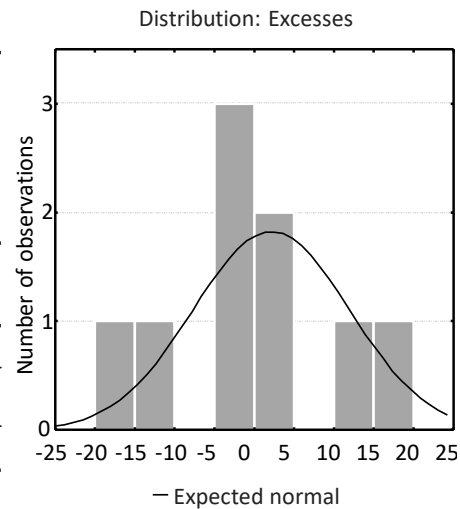

Table 3b. The results of regression for contributions from the members of Investor Compensation Fund (Czech Republic) contributions regression $(c)$ from its volume $(x)$

\begin{tabular}{|c|c|c|c|c|c|c|}
\hline \multirow[t]{2}{*}{$N=11$} & \multicolumn{6}{|c|}{$\begin{array}{l}\text { Regression results for dependent variable: contributions (data matrix 1) } \\
R=.93429652 ; R^{2}=.87290999 . \text { Corrected } R^{2}=.78818332 . \\
F(4,6)=10.303 ; \quad p<.00743 \text {. Standard error of estimate: } 15.094 .\end{array}$} \\
\hline & BETA & $\begin{array}{c}\text { Standard } \\
\text { error BETA }\end{array}$ & B & $\begin{array}{c}\text { Standard } \\
\text { error B }\end{array}$ & $t(6)$ & $p$-level \\
\hline Free term & - & - & 37.7815 & 20.49957 & 1.84304 & 0.114894 \\
\hline fund & 3.32966 & 1.262946 & 0.4685 & 0.17769 & 2.63643 & 0.038725 \\
\hline $\cos$ & -0.36593 & 0.183583 & -14.9621 & 7.50621 & -1.99329 & 0.093289 \\
\hline$V_{2}^{4}$ & 2.85853 & 1.051306 & 0.0000 & 0.00000 & 2.71903 & 0.034687 \\
\hline$V_{2}^{2}$ & -5.10639 & 2.140771 & -0.0008 & 0.00035 & -2.38530 & 0.054373 \\
\hline
\end{tabular}

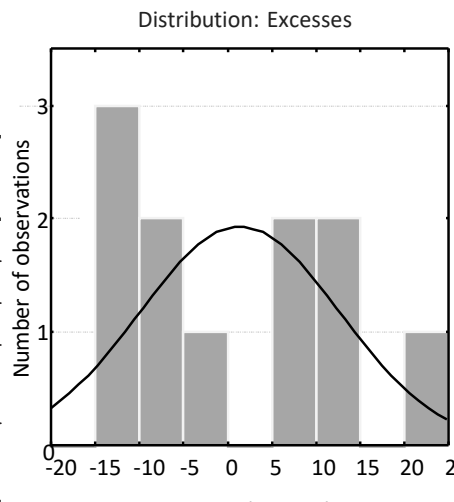

Table 3c. The results of regression for operating costs of the Investor Compensation Fund (Czech Republic) (e) from the volume of the fund $(x)$

\begin{tabular}{|c|c|c|c|c|}
\hline \multirow[t]{2}{*}{$N=9$} & \multicolumn{4}{|c|}{$\begin{array}{l}\text { Regression results for dependent variable: } \cos \\
\text { operating expenses) } \\
R=0.98013760 ; \quad R^{2}=0.96066972 . \text { Corrected } \\
F(2,6)=73.277 ; \quad p<.00006 . \text { Standard error }\end{array}$} \\
\hline & BETA & $\begin{array}{c}\text { Standard } \\
\text { error BETA }\end{array}$ & B & $\begin{array}{l}\text { Standa } \\
\text { error } E\end{array}$ \\
\hline Free term & - & - & 43.64289 & \\
\hline$x$ & -0.974979 & 0.081129 & -0.04515 & 0.0037 \\
\hline $\sin x$ & 0.180333 & 0.081129 & 2.61620 & $1.176 \mathrm{C}$ \\
\hline $\begin{array}{l}c=37.78 \\
e=43.64 \\
e=43.64 \\
\frac{x}{a} \geq 0.05 \\
x, y \geq 0\end{array}$ & $\begin{array}{r}5+0.4685 \cdot x \\
289-0.04515 \\
289-0.04515\end{array}$ & $\begin{array}{l}-14.9621 \cdot \cos \\
x+2.6162 \cdot \sin \\
x+2.6162 \cdot \sin \end{array}$ & $\begin{array}{l}-0.0008 \\
x \leq 46.2 \\
x \geq 22.16\end{array}$ & $\geq 92.22$ \\
\hline
\end{tabular}

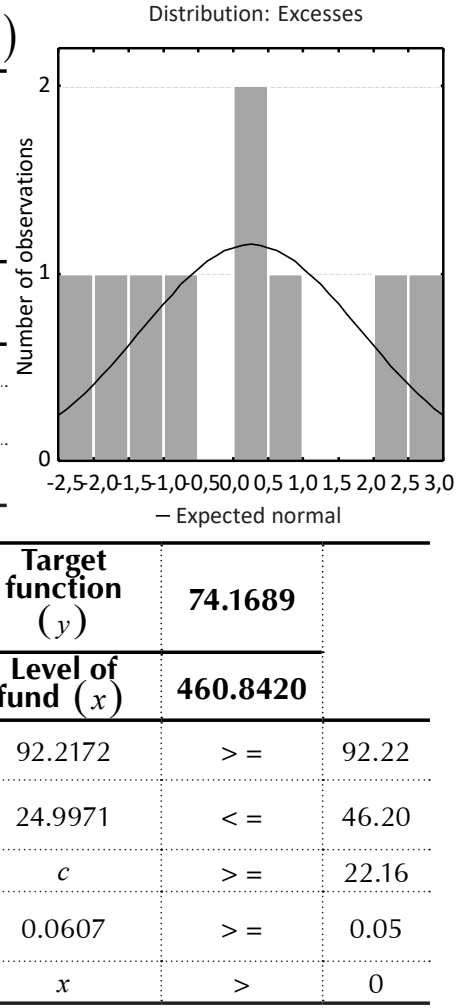




\section{FINANCIAL SERVICES COMPENSATION SCHEME (UNITED KINGDOM)}

Table 4a. The results of regression for standard deviation of the size of the Financial Services Compensation Scheme (FSCS) $(y)$ from its volume $(x)$

\begin{tabular}{|c|c|c|c|c|c|c|}
\hline \multirow[t]{2}{*}{$N=9$} & \multicolumn{6}{|c|}{$\begin{array}{l}\text { Regression results for dependent variable: risk (United Kingdom } \\
\text { target function) } \\
R=0.99921163 ; \quad R^{2}=0.99842389 . \text { Corrected } R^{2}=0.99684778 \\
F(4,4)=633.47 ; \quad p<.00001 . \text { Standard error of estimate: } 18.065\end{array}$} \\
\hline & BETA & $\begin{array}{c}\text { Standard } \\
\text { error } \\
\text { BETA }\end{array}$ & B & $\begin{array}{c}\text { Standard } \\
\text { error B }\end{array}$ & $t(4)$ & $p$-level \\
\hline Free term & - & - & 7.47636 & 13.39856 & 0.5580 & 0.606601 \\
\hline$x$ & 2.83842 & 0.124808 & 0.10010 & 0.00440 & 22.7423 & 0.000022 \\
\hline$x^{3}$ & -1.90910 & 0.127825 & -0.0000000002 & 0.00000 & -14.9353 & 0.000117 \\
\hline $\sin x$ & 0.06022 & 0.025227 & 29.16398 & 12.21778 & 2.3870 & 0.075412 \\
\hline$(\cos x)^{3}$ & 0.04558 & 0.027803 & 25.25500 & 15.40588 & 1.6393 & 0.176492 \\
\hline
\end{tabular}

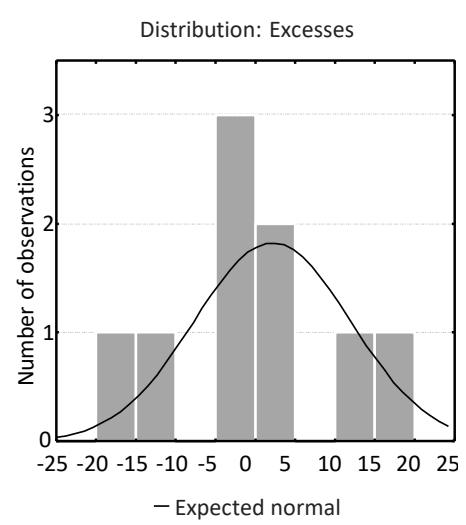

Table $\mathbf{4 b}$. The results of regression for contributions of the members of the Financial Services Compensation Scheme (FSCS) $(c)$ from its volume $(x)$

\begin{tabular}{|c|c|c|c|c|c|c|}
\hline \multirow[t]{2}{*}{$N=13$} & \multicolumn{6}{|c|}{$\begin{array}{l}\text { Regression results for dependent variable: } \operatorname{costs} \text { (United Kingdom } \\
\text { contributions) } \\
\begin{array}{l}R=0.94102557 ; \quad R^{2}=0.88552912 . \text { Corrected } R^{2}=0.84737216 . \\
F(3,9)=23.208 ; \quad p<.00014 . \text { Standard error of estimate: } 164.25 \text {. }\end{array}\end{array}$} \\
\hline & BETA & $\begin{array}{c}\text { Standard } \\
\text { error } \\
\text { BETA }\end{array}$ & B & $\begin{array}{c}\text { Standard } \\
\text { error B }\end{array}$ & $t(9)$ & $p$-level \\
\hline Free term & - & - & 15.4310 & 95.10092 & 0.16226 & 0.874686 \\
\hline$x$ & 3.81874 & 0.675818 & 0.1740 & 0.03079 & 5.65055 & 0.000313 \\
\hline$x^{3}$ & -3.14969 & 0.654141 & -0.0000000004 & 0.00000 & -4.81500 & 0.000954 \\
\hline $\cos x$ & 0.19202 & 0.158748 & 117.6476 & 97.26410 & 1.20957 & 0.257257 \\
\hline
\end{tabular}

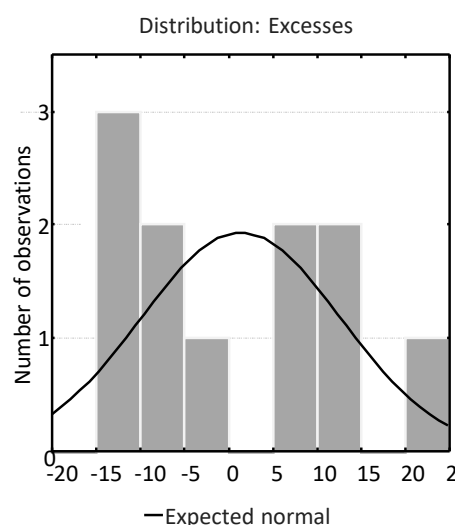

Table 4c. The results of regression for operating costs of the Financial Services Compensation Scheme (FSCS) $(e)$ from the volume of the fund $(x)$

\begin{tabular}{|c|c|c|c|c|c|c|}
\hline \multirow[t]{2}{*}{$N=13$} & \multicolumn{6}{|c|}{$\begin{array}{l}\text { Regression results for dependent variable: costs (data matrix 1) } \\
R=.94633921 ; R^{2}=.89555789 . \text { Corrected } R^{2}=.87466947 \\
F(2,10)=42.873 ; \quad p<.00001 . \text { Standard error of estimate: } 7.9940 .\end{array}$} \\
\hline & BETA & $\begin{array}{c}\text { Standard } \\
\text { error } \\
\text { BETA } \\
\end{array}$ & B & $\begin{array}{c}\text { Standard } \\
\text { error B }\end{array}$ & $t(10)$ & $p$-level \\
\hline Free term & - & - & 15.97801 & 3.648719 & 4.37907 & 0.001379 \\
\hline fund & 4.86726 & 0.832924 & 0.01191 & 0.002038 & 5.84358 & 0.000163 \\
\hline$V_{2}^{2}$ & -4.09637 & 0.832924 & -0.0000005289 & 0.000000 & -4.91806 & 0.000607 \\
\hline
\end{tabular}

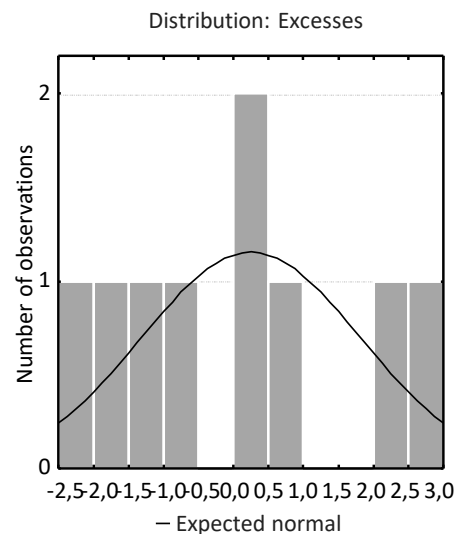




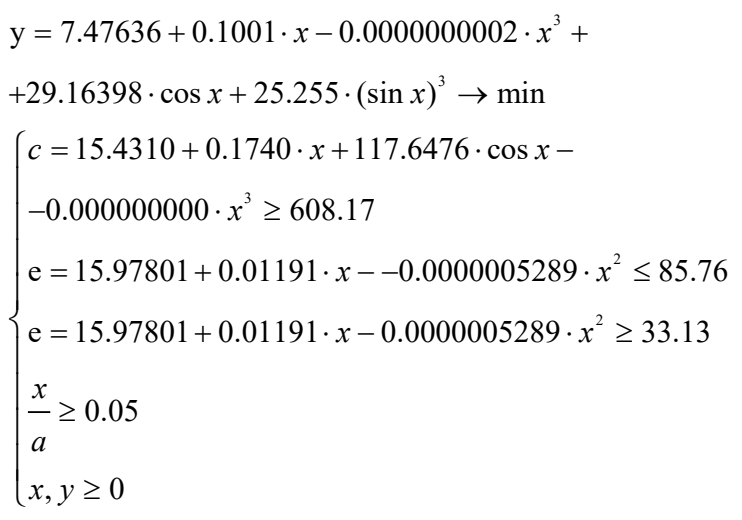

\begin{tabular}{|c|c|c|c|}
\hline & $\begin{array}{c}\begin{array}{c}\text { Target } \\
\text { function }\end{array} \\
(y)\end{array}$ & 760.3547 & \\
\hline & $\begin{array}{l}\text { Level of fund } \\
\qquad(x)\end{array}$ & 15969.8478 & \\
\hline Fee limitations $(b)$ & 1115.0855 & $>=$ & 608.17 \\
\hline \multirow[t]{2}{*}{$\begin{array}{l}\text { Operating cost } \\
\text { limitations }(c)\end{array}$} & 71.2903 & $<=$ & 85.76 \\
\hline & C & $>=$ & 33.13 \\
\hline \multirow[t]{2}{*}{ Level of fund limitation } & 0.1324 & $>=$ & 0.05 \\
\hline & $x$ & $>$ & 0 \\
\hline
\end{tabular}

\section{THE FONDS DEGARANTIEDES DÉPÔTS ET DE RÉSOLUTION (FRANCE)}

Table 5a. The results of regression for standard deviation of the size of the The Fonds degarantiedes dépôts et de résolution (FGDR) (France) $(y)$ from its volume $(x)$

\begin{tabular}{|c|c|c|c|c|c|c|}
\hline \multirow[t]{2}{*}{$N=11$} & \multicolumn{6}{|c|}{$\begin{array}{l}\text { Regression results for dependent variable: } r i s k \text { (France target } \\
\text { function) } \\
R=0.93293925 ; \quad R^{2}=0.87037565 . \text { Corrected } R^{2}=0.81482235 \\
F(3,7)=15.667 ; \quad p<.00173 \text {. Standard error of estimate: } 61.656 \text {. }\end{array}$} \\
\hline & BETA & $\begin{array}{c}\text { Standard } \\
\text { error } \\
\text { BETA }\end{array}$ & B & $\begin{array}{c}\text { Standard } \\
\text { error B }\end{array}$ & $t(7)$ & $p$-level \\
\hline Free term & - & - & -1638.5854400113 & 355.4743 & -4.60958 & 0.002456 \\
\hline$x$ & 4.43839 & 0.912727 & 1.0707154794 & 0.2202 & 4.86278 & 0.001829 \\
\hline$x^{3}$ & -3.77953 & 0.922843 & -0.0000000464 & 0.0000 & -4.09553 & 0.004599 \\
\hline$(\cos x)^{2}$ & 0.22417 & 0.147086 & 109.0852609585 & 71.5737 & 1.52410 & 0.171308 \\
\hline
\end{tabular}

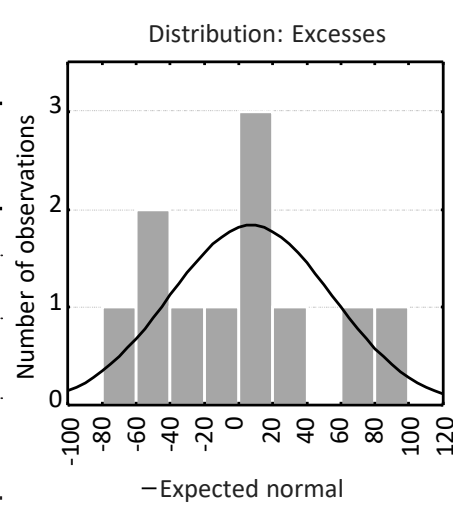

Table $\mathbf{5 b}$. The results of regression for contributions of the members of the Fonds de Guarantee des Dépôts et de Résolution (FGDR) (France) $(c)$ from its volume $(x)$

\begin{tabular}{|c|c|c|c|c|c|c|}
\hline \multirow[t]{2}{*}{$N=13$} & \multicolumn{6}{|c|}{$\begin{array}{l}\text { Regression results for dependent variable: contributions } \\
\text { (France contributions) } \\
R=0.94068591 ; \quad R^{2}=0.88488998 . \text { Corrected } R^{2}=0.86186798 \\
F(2,10)=38.437 ; \quad p<.00002 . \text { Standard error of estimate: } 67.968 .\end{array}$} \\
\hline & BETA & $\begin{array}{c}\text { Standard } \\
\text { error } \\
\text { BETA }\end{array}$ & B & $\begin{array}{c}\text { Standard } \\
\text { error B }\end{array}$ & $t(10)$ & $p$-level \\
\hline Free term & - & - & -1678.4121280469 & 266.5725 & -6.29627 & 0.000090 \\
\hline$x$ & 4.23905 & 0.645827 & 1.1169765190 & 0.1702 & 6.56375 & 0.000064 \\
\hline$x^{3}$ & -3.55647 & 0.645827 & -0.0000000451 & 0.0000 & -5.50685 & 0.000259 \\
\hline
\end{tabular}

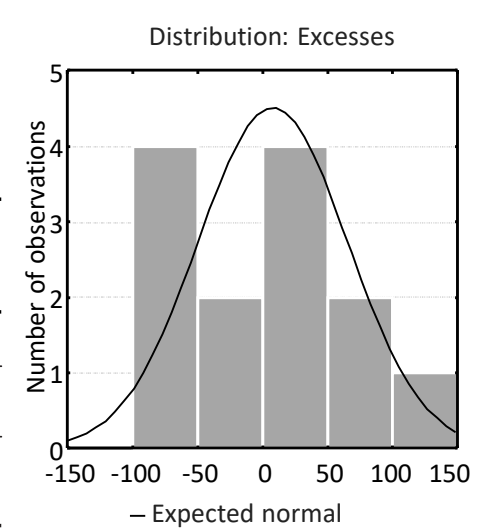


Table 5c. The results of regression for operating costs of The Funds of the Guarantee for Dépôts et de Résolution (FGDR) (France) $(e)$ from the fund's volume $(x)$

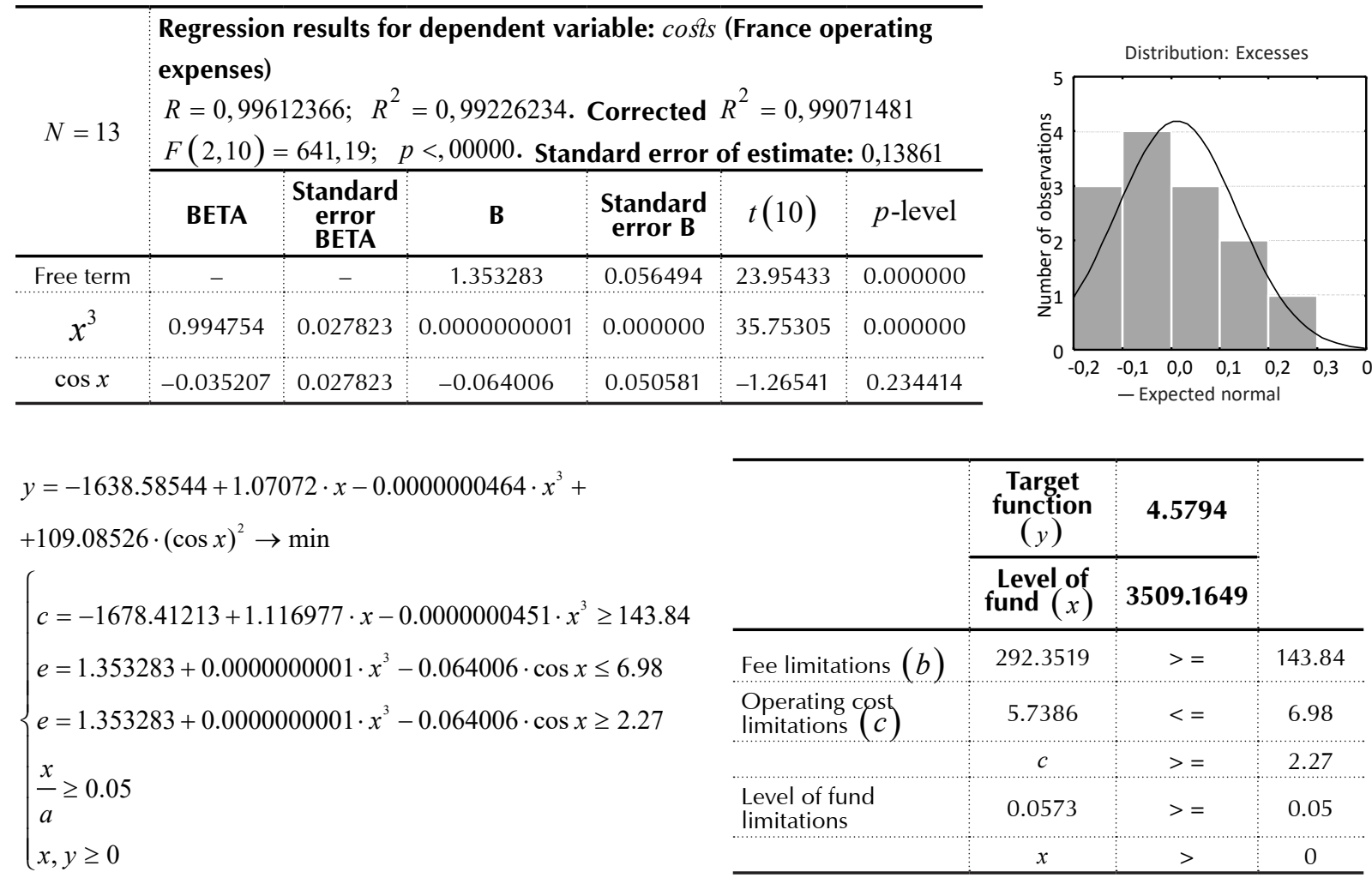

\section{INVESTOR COMPENSATION COMPANY LIMITED (IRELAND)}

Table 6a. The results of regression for standard deviation of the size of the Investor Compensation Company Limited (Ireland) $(y)$ from its volume $(x)$

\begin{tabular}{|c|c|c|c|c|c|c|}
\hline \multirow[t]{2}{*}{$N=12$} & \multicolumn{6}{|c|}{$\begin{array}{l}\text { Regression results for dependent variable: } \text { risk (Ireland target } \\
\text { function) } \\
R=0.97927491 ; \quad R^{2}=0.95897935 . \text { Corrected } R^{2}=0.92479548 \\
F(5,6)=28.054 ; \quad p<.00043 \text {. Standard error of estimate: } 272.48 \text {. }\end{array}$} \\
\hline & BETA & $\begin{array}{c}\text { Standard } \\
\text { error BETA }\end{array}$ & B & $\begin{array}{c}\text { Standard } \\
\text { error B }\end{array}$ & $t(6)$ & $p$-level \\
\hline Free term & - & - & -5472.023510 & 1113.588 & -4.91387 & 0.002673 \\
\hline$x$ & 14.4732 & 1.926448 & 1.217279 & 0.162 & 7.51287 & 0.000288 \\
\hline$x^{2}$ & -25.8000 & 4.082374 & -0.000043 & 0.000 & -6.31984 & 0.000733 \\
\hline$x^{3}$ & 12.4863 & 2.278247 & 0.0000000005 & 0.000 & 5.48067 & 0.001542 \\
\hline $\cos x$ & 1.2016 & 0.306005 & 1773.422915 & 451.633 & 3.92669 & 0.007742 \\
\hline$(\cos x)^{3}$ & -0.8348 & 0.284662 & -1612.871341 & 549.988 & -2.93256 & 0.026200 \\
\hline
\end{tabular}

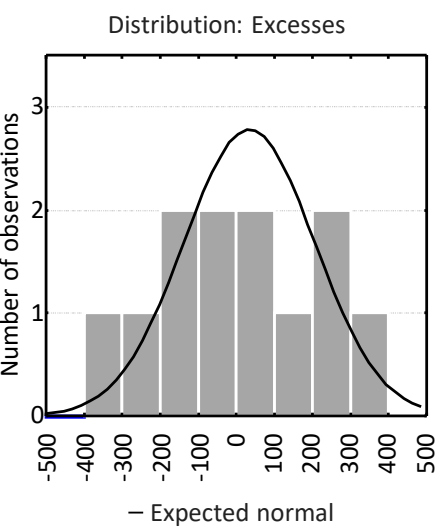


Table $6 \mathbf{b}$. The results of regression for contributions of the members of the Investor Compensation Company Limited (Ireland) $(c)$ from its volume $(x)$

\begin{tabular}{|c|c|c|c|c|c|c|}
\hline \multirow[t]{2}{*}{$N=14$} & \multicolumn{6}{|c|}{$\begin{array}{l}\text { Regression results for dependent variable: contributions (Ireland } \\
\text { contributions) } \\
R=0.97108080 ; R^{2}=0.94299792 . \text { Corrected } R^{2}=0.92589729 . \\
F(3,10)=55.144 ; \quad p<.00000 . \text { Standard error of estimate: } 268.57 \text {. }\end{array}$} \\
\hline & BETA & $\begin{array}{c}\text { Standard } \\
\text { error BETA }\end{array}$ & B & $\begin{array}{c}\text { Standard } \\
\text { error B }\end{array}$ & $t(10)$ & $p$-level \\
\hline Free term & - & - & 2820.037854 & 224.1513 & 12.58096 & 0.000000 \\
\hline$x$ & 0.914981 & 0.089921 & 0.066207 & 0.0065 & 10.17535 & 0.000001 \\
\hline$(\cos x)^{3}$ & -0.144858 & 0.096363 & -272.555946 & 181.3119 & -1.50324 & 0.163682 \\
\hline$(\sin x)^{2}$ & 0.109150 & 0.084475 & 287.200714 & 222.2754 & 1.29209 & 0.225385 \\
\hline
\end{tabular}

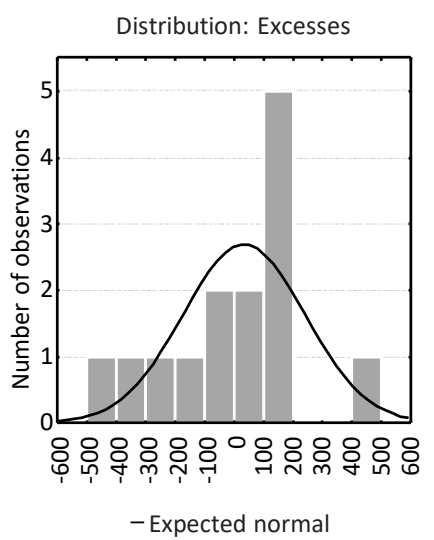

Table 6c. The results of regression for operating costs of Investor Compensation Company Limited (Ireland) $(e)$ from the fund's volume $(x)$

\begin{tabular}{|c|c|c|c|}
\hline \multirow[t]{2}{*}{$N=14$} & \multicolumn{3}{|c|}{$\begin{array}{l}\text { Regression results for dependent varia } \\
\text { expenses) } \\
R=0.92834912 ; \quad R^{2}=0.86183208 \text {. Co } \\
F(1,12)=74.851 ; \quad p<.00000 \text {. Standa }\end{array}$} \\
\hline & BETA & $\begin{array}{c}\text { Standard } \\
\text { error } \\
\text { BETA }\end{array}$ & B \\
\hline Free term & - & - & 421.799015 \\
\hline$x$ & 0.928349 & 0.107303 & 0.024065 \\
\hline \multicolumn{4}{|c|}{$\mathrm{y}=-5472.02351+1.217279 \cdot x-0.000043 \cdot x^{2}+$} \\
\hline \multicolumn{4}{|c|}{$+0.0000000005 \cdot x^{3}+1773.422915 \cdot \cos x-$} \\
\hline \multicolumn{4}{|c|}{$-1612.871341 \cdot(\cos x)^{3} \rightarrow \min$} \\
\hline \multicolumn{4}{|c|}{$\int c=2820.037854+0.066207 \cdot x-272.555946 \cdot(\cos x)^{3}$} \\
\hline \multicolumn{4}{|c|}{$+287.200714 \cdot(\sin x)^{2} \geq 3838.02$} \\
\hline \multicolumn{4}{|c|}{$e=421.799015+0.024065 \cdot x \leq 1839.6$} \\
\hline \multicolumn{4}{|c|}{$e=421.799015+0.024065 \cdot x \geq 853.12$} \\
\hline \multicolumn{4}{|l|}{$-\geq 0.05$} \\
\hline \multicolumn{4}{|l|}{$x, y \geq 0$} \\
\hline
\end{tabular}

\begin{tabular}{|c|c|c|c|}
\hline & $\begin{array}{c}\text { Target } \\
\text { function } \\
(y)\end{array}$ & 12889.2036 & \\
\hline & $\begin{array}{c}\text { Level of } \\
\text { fund }(x)\end{array}$ & 53999.9153 & \\
\hline Fee limitations $(b)$ & 6637.6348 & $>=$ & 3838.02 \\
\hline \multirow[t]{2}{*}{$\begin{array}{l}\text { Operating cost } \\
\text { limitations }(c)\end{array}$} & 1721.3070 & $<=$ & 1839.60 \\
\hline & $c$ & $>=$ & 853.12 \\
\hline \multirow[t]{2}{*}{$\begin{array}{l}\text { Level of fund } \\
\text { limitations }\end{array}$} & 0.0505 & $>=$ & 0.05 \\
\hline & $x$ & $>$ & 0 \\
\hline
\end{tabular}




\section{INVESTOR COMPENSATION SCHEME (MALTA)}

Table 7a. The results of regression for standard deviation of the size of the Investor Compensation Scheme (Malta) $(y)$ from its volume $(x)$

\begin{tabular}{|c|c|c|c|c|c|c|}
\hline \multirow[t]{2}{*}{$N=9$} & \multicolumn{6}{|c|}{$\begin{array}{l}\text { Regression results for dependent variable: risk (Malta target } \\
\text { function) } \\
\begin{array}{l}R=0.94995547 ; \quad R^{2}=0.90241540 . \text { Corrected } R^{2}=0.86988719 . \\
F(2,6)=27.743 ; \quad p<.00093 \text {. Standard error of estimate: } 91.487 \text {. }\end{array}\end{array}$} \\
\hline & BETA & $\begin{array}{c}\text { Standard } \\
\text { error BETA }\end{array}$ & B & $\begin{array}{c}\text { Standard } \\
\text { error B }\end{array}$ & $t(6)$ & $p$-level \\
\hline Free term & - & - & -6.591868 & 58.28564 & -0.113096 & 0.913644 \\
\hline$x^{2}$ & 0.903620 & 0.127585 & 0.000103 & 0.00001 & 7.082487 & 0.000397 \\
\hline$(\sin x)^{2}$ & 0.267860 & 0.127585 & 149.836478 & 71.36898 & 2.099462 & 0.080538 \\
\hline
\end{tabular}

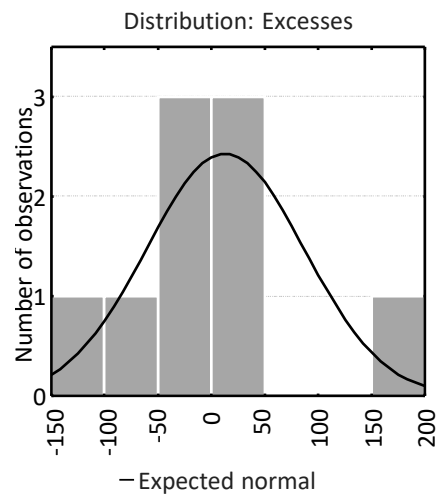

Table $\mathbf{7 b}$. The results of regression for contributions of the members of the Investor Compensation Scheme (Malta) $(c)$ from its volume $(x)$

\begin{tabular}{|c|c|c|c|c|c|c|}
\hline \multirow[t]{2}{*}{$N=12$} & \multicolumn{6}{|c|}{$\begin{array}{l}\text { Regression results for dependent variable: contributions (Malta } \\
\text { contributions) } \\
R=0.91134132 ; \quad R^{2}=0.83054300 . \text { Corrected } R^{2}=0.76699662 \text {. } \\
F(3,8)=13.070 ; \quad p<.00189 . \text { Standard error of estimate: } 56.729 \text {. }\end{array}$} \\
\hline & BETA & $\begin{array}{c}\text { Standard } \\
\text { error BETA } \\
\end{array}$ & B & \begin{tabular}{|c|} 
Standard \\
error B
\end{tabular} & $t(8)$ & $p$-level \\
\hline Free term & - & - & 19.852382 & 37.0607 & 0.53567 & 0.606753 \\
\hline$x$ & 0.82413 & 0.175202 & 0.123754 & 0.0263 & 4.70388 & 0.001534 \\
\hline $\sin x$ & -1.12327 & 0.689107 & -188.643258 & 115.7297 & -1.63003 & 0.141742 \\
\hline$(\sin x)^{3}$ & 0.98221 & 0.718506 & 185.253272 & 135.5160 & 1.36702 & 0.208794 \\
\hline
\end{tabular}

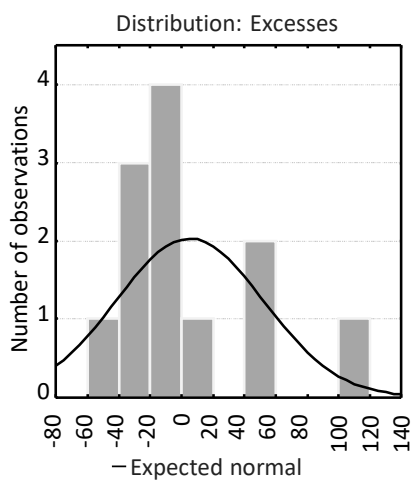

Table 7c. The results of regression for operating costs of the Investor Compensation Scheme (Malta) $e$ from the volume of the fund $(x)$

\begin{tabular}{|c|c|c|c|c|c|c|}
\hline \multirow[t]{2}{*}{$N=10$} & \multicolumn{6}{|c|}{$\begin{array}{l}\text { Regression results for dependent variable: costs (Malta operating } \\
\text { expenses) } \\
R=0.97357558 ; \quad R^{2}=0.94784940 . \text { Corrected } R^{2}=0.92177411 \\
F(3,6)=36.350 ; \quad p<.00030 . \text { Standard error of estimate: } 1.6822\end{array}$} \\
\hline & BETA & $\begin{array}{c}\text { Standard } \\
\text { error } \\
\text { BETA }\end{array}$ & B & $\begin{array}{c}\text { Standard } \\
\text { error B }\end{array}$ & $t(6)$ & $p$-level \\
\hline Free term & - & - & 1.36112643 & 1.431875 & 0.95059 & 0.378516 \\
\hline$x$ & 2.15463 & 0.334204 & 0.01523202 & 0.002363 & 6.44704 & 0.000659 \\
\hline$x^{2}$ & -1.31176 & 0.334227 & -0.00000345 & 0.000001 & -3.92477 & 0.007759 \\
\hline$(\sin x)^{2}$ & 0.12968 & 0.093317 & 1.58555314 & 1.140977 & 1.38965 & 0.214007 \\
\hline
\end{tabular}

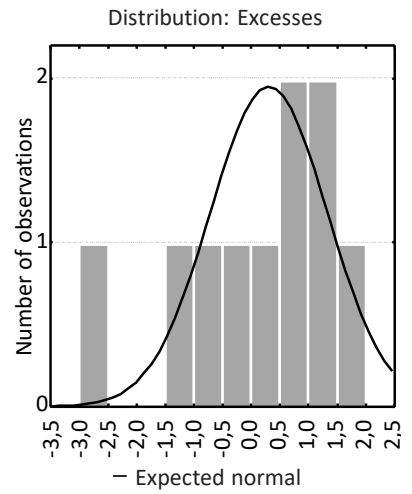




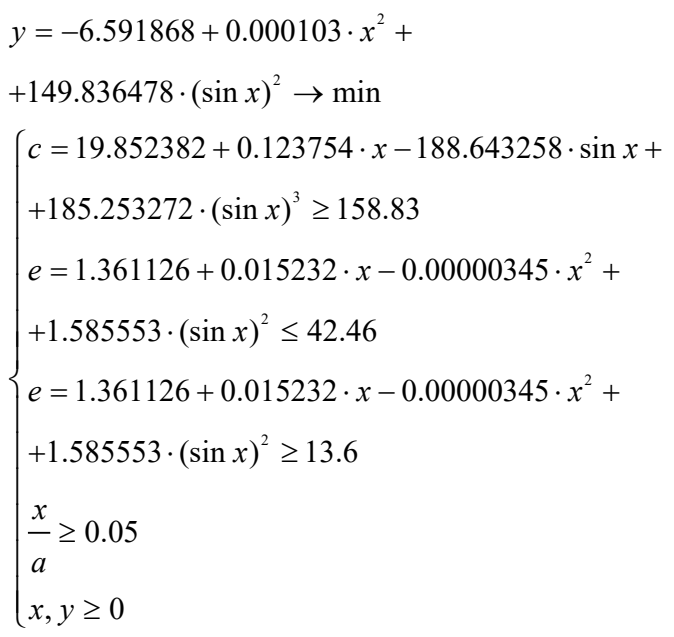

\begin{tabular}{l|c:c:c}
\hline & $\begin{array}{c}\text { Target } \\
\text { function }(y)\end{array}$ & 393.0507 & \\
\cline { 2 - 3 } & $\begin{array}{c}\text { Level of fund } \\
(x)\end{array}$ & $\mathbf{1 9 6 9 . 7 7 7 2}$ & \\
\hline Fee limitations $(b)$ & 263.3591 & $>=$ & 158.83 \\
\hdashline Operating cost & 17.9787 & $<=$ & 42.46 \\
limitations $(c)$ & $c$ & $>=$ & 13.60 \\
\hdashline Level of fund limitations & 0.0928 & $>=$ & 0.05 \\
\hline & $x$ & $>\ldots . .$. \\
\hline
\end{tabular}

